\title{
Firm-level Investment Under Imperfect Capital Markets in Ukraine
}

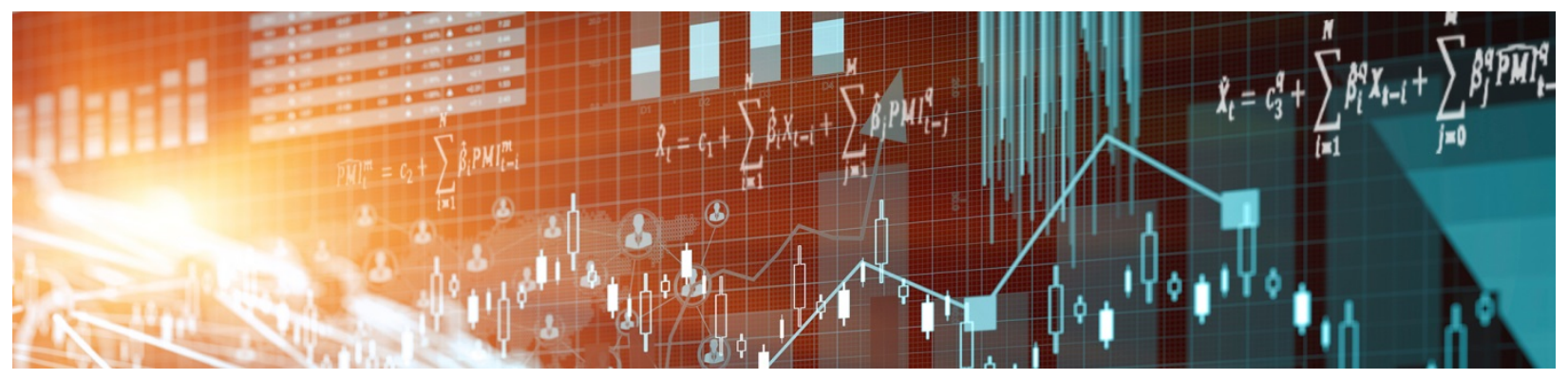

by Oleksandr Shcherbakov 
Bank of Canada Staff Working Paper 2019-14

April 2019

\title{
Firm-level Investment Under Imperfect Capital Markets in Ukraine
}

\author{
by \\ Oleksandr Shcherbakov \\ Currency Department \\ Bank of Canada \\ Ottawa, Ontario, Canada \\ AShcherbakov@bank-banque-canada.ca
}




\section{Acknowledgements}

I would like to thank Gautam Gowrisankaran, Daniel Ackerberg, Yuya Takahashi, Tim Lee and Gregory Crawford for their valuable comments and advice. Special thanks to Ben Fung and Kim P. Huynh for their suggestions and support during the entire revision process. All errors are mine. 


\begin{abstract}
This paper develops and estimates a model of firm-level fixed capital investment when firms face borrowing constraints. Dynamically optimal investment functions are derived for the firms with and without financial constraints. These policy functions are then used to construct the likelihood of observing each of the investment regimes in the data. Structural parameters are estimated using data from the Ukrainian manufacturing sector in 1993-1998. I provide empirical evidence of the role of market and ownership structure for firm-level investment behavior. I also discuss the effects of international trade exposure and involvement in non-monetary transactions on the probability of facing financial constraints and the resulting fixed capital accumulation path. Estimation results are used to illustrate the welfare implications of financial constraints in the Ukrainian manufacturing sector.
\end{abstract}

Bank topics: Econometric and statistical methods; Economic models; Firm dynamics JEL codes: C61, C63, D24, G31

\title{
Résumé
}

Dans cette étude, je mets au point et estime un modèle d'investissement en capital fixe par des entreprises faisant face à des contraintes d'emprunt. En l'appliquant, j'obtiens les fonctions d'investissement dynamiquement optimales pour les entreprises soumises à des contraintes financières et pour celles qui ne le sont pas. Ces fonctions de décision sont ensuite utilisées pour déterminer, dans les données, la probabilité d'observer chaque régime d'investissement. Les paramètres structurels sont estimés au moyen de données sur le secteur manufacturier ukrainien recueillies entre 1993 et 1998. Je fournis des résultats empiriques quant au rôle que jouent les structures de marché et de propriété dans les décisions en matière d'investissement. Je décris aussi comment la participation des entreprises au commerce international et à des opérations non monétaires influe sur la probabilité qu'elles se heurtent à des contraintes financières, et quel sentier d'accumulation du capital fixe en découle. Les résultats de l'estimation sont utilisés pour décrire les conséquences qu'ont sur le bien être les contraintes financières présentes dans le secteur manufacturier de l'Ukraine.

Sujets : Méthodes économétriques et statistiques; Modèles économiques; Dynamique des entreprises

Codes JEL : C61, C63, D24, G31 


\section{Non-Technical Summary}

Studies of investment behavior and its determinants play an important role in the macroeconomic analysis of resource allocation, theories of business cycles and the design of public policy, which are all the prerequisites for long-term growth. Asymmetric information, agency and transaction costs are the major reasons for the existence of a financial hierarchy, when firms rely heavily on internal finance for their fixed capital investment.

The main contribution of this study is that it identifies a subset of firms that face borrowing restrictions without imposing ad hoc assumptions on the characteristics of these firms. In the earlier literature, financial constraints are typically identified using various cash flow sensitivity tests. The tests would classify firms into constrained and unconstrained using some observable characteristics. Then, cash flow variables would be included in an empirical investment equation and their statistical significance discussed. In this paper, a structural model endogenously classifies firms into constrained and unconstrained based on their observed behavior. By exploring the characteristics of the firms identified as constrained, one can help in validating the assumptions made in the earlier literature.

In this paper, I study firm-level investment behavior in 1993-1998 in a transition economy characterized by economic uncertainty and significant asymmetries in the information environment between potential borrowers and lenders. Dynamically optimal investment policy requires access to external sources, if firms' own profits are not sufficient. When the cost of borrowing is prohibitively high, the firms' investment level would be lower than the optimal one. There is another way in which the investment policy of a firm that has access to external resources (unconstrained) can be different from a firm that cannot borrow (constrained). For example, a constrained firm may find it optimal to over-invest relative to the unconstrained one in some periods, because increasing capital stock today not only increases the firm's expected net present value of the future cash flows, but also reduces the probability of having to borrow in the future. To account for this type of strategic incentives, I use a nested fixed-point algorithm, which works as follows. For given values of parameters, the algorithm solves for optimal firm-level investment policy as a function of a vector of payoff-relevant variables such as current level of capital stock and its marginal profitability. Then this policy function is matched to the observed data and the differences represent residuals that are used in estimation.

Results in this paper are consistent with the previous findings in the literature that relatively young and potentially fast-growing firms are likely to be harmed the most. By estimating the model using data from the Ukrainian manufacturing industries, I find that on average only about 23 to 30 percent of the firms in Ukrainian manufacturing could borrow in 19931998. Two exceptions are the food-related and electricity generation industries, with 15 and 60 percent of the firms having access to external funds, respectively. Over time, the number of constrained firms declined significantly in all industries but electricity generation. State ownership is associated with a much higher likelihood of financial constraints, while industry concentration helps in reducing them. Exporting firms were identified as experiencing borrowing restrictions with a higher probability than domestically-oriented producers. Finally, high volumes of non-monetary transactions such as barter and toll schemes can significantly increase the probability of financial constraints. 


\section{Introduction}

Studies of investment behavior and its determinants play an important role in the macroeconomic analysis of resource allocation, theories of business cycles and proper design of public policy, which are all prerequisites for long-term growth. Asymmetric information, agency and transaction costs are the major reasons for the existence of a financial hierarchy in developed countries, in which firms rely heavily on internal finance for their investment projects. Obviously, these problems are much more severe in transition economies. Underdeveloped capital markets and high uncertainty make the costs of external project financing significantly higher than that of retained earnings. Not surprisingly, in many firm-level surveys managers report corporate profits as the main source for investments.

In this paper, I study firm-level investment behavior in a transition economy characterized by economic uncertainty and significant asymmetries in the information environment between potential borrowers and lenders. It is hypothesized that some of the firms facing financial constraints cannot afford the optimal level of investment predicted by their intertemporal maximization problem. Deviations from an optimal capital accumulation path may vary with the firms' size, reputation, ownership structure, etc. For example, earlier literature on financial constraints suggests that young and potentially fast-growing firms are likely to be harmed the most (e.g., Calomiris and Hubbard, 1995).

The theory of the financial hierarchy, where internal and external sources of finance are not perfect substitutes, is based on an information asymmetry between borrowers and lenders. Due to the information imperfections, the cost of external funds increases through excessive risk premiums in the interest rates faced by borrowers. In "agency cost" models, there is a conflict of interest between managers and external shareholders. This conflict can result in excessive monitoring and reduced managerial flexibility since outside shareholders attempt to control managers. This may lead to direct increases in the associated costs of control and to foregone profit opportunities. Additional differences between the costs of internal and external funds may be due to transaction costs, including registration fees, underwriting discounts and the selling expenses related to the procedure of bonds and stocks issuance. The difference in the taxation of dividends and capital gains can further contribute to the difference in costs of external and internal finance. Calomiris and Hubbard (1995) employ firm-level data in 1933-1938, which provide them with an 
opportunity to measure the shadow price difference between external and internal finance due to a surtax on undistributed profits. The authors find that investment-cash flow sensitivity is entirely driven by the group of high-surtax-margin firms. Lamont (1997), in his study of non-oil subsidiaries of oil companies, shows that a decrease in cash flow and collateral value may lead to a decrease in investments. Oliner and Rudebusch (1992) use panel data on U.S. firms from the late 1970s and early 1980s. Although they state that information asymmetry is definitely an important factor determining firms' investment, they fail to find evidence in favor of the transaction cost argument. A good survey of theory and empirical models of investment can be found in Chirinko (1993). The problem of external versus internal financing is discussed from a variety of perspectives in Sinai and Eckstein (1983); Myers and Majluf (1984); Kopcke (1985); Fazzari and Mott (1986); Bernstein and Nadiri (1988); Calomiris and Hubbard (1990) and Hubbard (1998).

There are several ways to model financial constraints. Most of these methods use the idea of sensitivity of investments to the changes in cash flow or other internal worth variables in a theory-driven investment equation. Under the null hypothesis of no financial constraints, coefficients for these variables should not be statistically significant. Rejection of the null is interpreted as an indication of financial hierarchy. This approach was employed in Fazzari and Athey (1987) by using two variables capturing the financial constraints: flow of internal finance and interest expense. While the results support the hypothesis that cash flows affect firm-level investment behavior, the methodology has a serious caveat because it is unclear "whether the investment-cash flow sensitivity is a signal of financial constraints or merely a signal of expected profit." (Chatelain, 2002, p.6)

Various excess sensitivity tests, which add cash flow proxy variables to a standard Q-model of investment or an Euler equation and test for their significance, can also be used to conduct sample-splitting tests. These approaches require researchers to identify two groups of firms: one with a negligible premium for external finance and another with a high cost of external funds. Then the cash flow sensitivity tests can be applied to each group separately. For example, Fazzari et al. (1988) estimate an investment equation with financial variables for two separate groups of firms, classified by their dividend behavior. The authors conclude that "financial effects were generally important for investment in all firms. But the results consistently indicated a substantially greater sensitivity of investment to cash flow and liquidity in firms that retain nearly all of their 
income." (p.184)

A series of follow-up papers by Kaplan and Zingales (1997, 2000) and Fazzari et al. (2000) raise many questions, the most important of which is whether investment-cash flow sensitivity is monotone in the degree of financial constraints. ${ }^{1}$ A more recent attempt to explain the controversy is made by Hovakimian and Titman (2006), who point at the difficulties of measuring investment opportunities. To resolve the problem, the authors propose exploring the relationship between voluntary divestiture funds and firms' investments. Voluntary divestitures may represent an important financing resource for financially constrained firms. Since it is unlikely that asset sales are strongly related to the investment opportunities, finding that firms' investments are more sensitive to the asset sales for constrained firms supports the literature that considers investment sensitivity to cash flows as a sign of financial constraints. It is worth noting that the model used in the present study does not rely on Tobin's $q$ measure, nor does it assume any monotonicity in the relationship between financial constraints and investment-cash flow sensitivity. Therefore, results of this study can contribute to a better understanding of the problem when we investigate the characteristics of the firms identified to be financially constrained.

In this paper, I develop a structural model which does not rely on explicit assumptions about the characteristics of the financially constrained firms. Every period, each of the firms can be in one of the two mutually exclusive and exhaustive regimes: constrained or unconstrained. Firms in the unconstrained regime can borrow to finance their investments, while firms in the constrained regime have resources limited by their current period retained earnings only. The firms are fully aware of the regime they are operating under and expect this regime to continue forever, i.e., if the regime changes it comes as a surprise. Classification of the firms into constrained and unconstrained regimes is conducted based on the observed levels of profit, capital stock and investment. Given structural parameters, I can recover the total cost of the observed investment and compare it to the firm's own financial resources, summarized by its profits. If the observed level of investment exceeds its own funds, the firm is classified as unconstrained and vice versa. The main contribution of the paper is in the application of the nested fixed-point algorithm to solve for the

\footnotetext{
${ }^{1}$ The controversy comes from the fact that both groups of authors use the same data to arrive at opposite conclusions. Kaplan and Zingales (1997) find that the firms that are likely to be financially constrained exhibit the lowest sensitivity to the cash flow variable, while Fazzari et al. (1988) find the opposite relationship.
} 
dynamically optimal investment policy function with and without borrowing restrictions. Differently from the estimation based on the first-order conditions for dynamic controls (empirical Euler equations), the full solution allows constrained firms to anticipate and to endogenize borrowing restrictions in the future. In particular, for the firms without access to external funds, a unit of investment today not only increases future capital stock but also reduces the likelihood of having to borrow (or invest less) in the future.

Estimation of structural parameters is performed using the optimal two-step generalized method of moments (GMM) with an application of the nested fixed-point algorithm. In the inner loop of the algorithm, I solve the firm-level investment problem under alternative assumptions on the borrowing constraints. In particular, by solving two dynamic optimization problems, one for the firms that can borrow and another for those that cannot, I obtain unconstrained and constrained investment policy functions, respectively. Differences between the model predictions and observed data represent shocks that are used to form moment conditions and a GMM criterion function, which is minimized in the outer loop by searching over the vector of structural parameters.

Estimation results suggest that constrained firms tend to be smaller and have high returns on capital, which is consistent with the findings in the earlier literature. While the probability of facing financial constraints is estimated between 0.40 and 0.85 , for most industries, only about 23 to 30 percent of firms could borrow. Probability of operating in a constrained investment regime declined substantially in all industries but electricity generation. Losses in the long-run firm values due to financial constraints constitute about 1 percent of the unconstrained value function or 49 percent of the per-period profits. State ownership increases the probability of financial constraints, while industry concentration may be helpful in overcoming liquidity constraints. Export-oriented firms experience a higher likelihood of borrowing constraints. Significant engagement in non-monetary transactions such as barter and give-and-take-raw-materials (toll) schemes increases the probability of financial constraints.

The rest of the paper is organized as follows. Section 2 describes institutions in Ukrainian manufacturing, provides summary statistics for the data and discusses factors potentially affecting firm-level investment behavior. Section 3 describes a simple theory model of firm-level investment formulated as a single-agent dynamic programming problem. I provide reduced-form evidence of financial constraints using the empirical version of 
the Euler equation with additional cash flow variables. The evidence is provided for the entire sample as well as for the subgroups of firms with high and low return on capital. In Section 4, I discuss empirical specifications chosen for the structural model. Section 5 discusses parameter estimates and key findings using the structural model. Section 6 concludes.

\section{Data and institutional details}

Data for this study are based on the Ukrainian enterprise register, which is the official database of the Ministry of Statistics of Ukraine containing firm-level data in the manufacturing sector in 1993-1998. The total number of firms in the sample varies over time between about 7,536 and 9,115 individual establishments classified into nine 2-digit industry groups: electricity/power generation, ferrous metallurgy, chemical industry, machinery, woodworking, construction materials, light, food and other (food-related) industries. ${ }^{2}$ The sample is representative of the Ukrainian manufacturing sector. Firms in the sample employed 16 to 23 percent of the total labor force in Ukraine in 1993-1998. The dynamics of the number of firms and the share of the total labor force employed is summarized in Table 1.

Table 1: Data description, manufacturing sector, Ukraine, 1993-1998

\begin{tabular}{lcccccc}
\hline Variable & 1993 & 1994 & 1995 & 1996 & 1997 & 1998 \\
\hline \hline Labor/labor force & 0.23 & 0.21 & 0.20 & 0.18 & 0.16 & 0.16 \\
Number of firms & 8,378 & 7,536 & 8,601 & 8,525 & 8,442 & 9,115 \\
\hline \hline
\end{tabular}

Source: Ukrainian enterprise register, 1993-1998; own calculations.

Table 2 provides mean values for capital stock, labor, profits and investment variables used in the estimation analysis. All values are in 2011 U.S. dollars. Across industries, electricity generation, ferrous metallurgy and chemical industries typically have much larger firms in terms of both capital and labor than any of the remaining industries, including machinery, woodworking, production of construction materials, light, food and other food-related industries.

\footnotetext{
${ }^{2}$ Food-related industries are typically agricultural farms and related factories, for example, feed mills.
} 
Table 2: Summary statistics for capital stock, labor, profits and investment

\begin{tabular}{lcccc}
\hline & Capital & Labor & Profits & Investment \\
\hline \hline Electricity & $5,272,973.41$ & $1,483.19$ & $2,203,644.24$ & $456,003.57$ \\
Ferrous metallurgy & $3,488,534.19$ & $2,610.66$ & $830,530.93$ & $153,010.60$ \\
Chemical & $1,332,289.07$ & $1,100.53$ & $188,709.09$ & $54,894.52$ \\
Machinery & $492,543.35$ & 849.79 & $72,653.07$ & $17,578.19$ \\
Woodworking & $163,535.70$ & 305.21 & $35,414.62$ & $7,444.64$ \\
Construction materials & $180,652.74$ & 263.92 & $24,990.98$ & $7,200.19$ \\
Light & $136,641.48$ & 461.23 & $35,460.89$ & $4,337.06$ \\
Food & $161,588.09$ & 210.60 & $87,028.01$ & $12,276.77$ \\
Other (food-processing) & $124,091.60$ & 127.17 & $66,096.40$ & $6,636.44$ \\
\hline \hline
\end{tabular}

Source: Ukrainian enterprise register, 1993-1998; own calculations, USD 2011. Summary statistics are for the full sample. In estimation, about 5 percent of the largest firms in each industry are excluded.

Note that in estimation, I exclude about 5 percent of the largest firms from each industry. This is done for two reasons. First, such firms are likely to be state-owned or can be deemed too big to fail and, hence, may behave differently from the rest of the profit-maximizing firms. ${ }^{3}$ Second, a numerical solution to a dynamic programming problem should be more accurate, when firms are more homogeneous in size. This is because their value and policy functions are defined on a relatively fine grid instead of a crude approximation with wide grids when large outliers are included.

In 1993-1998, the Ukrainian economy was undergoing significant changes in terms of ownership structure, market competitiveness and firms' involvement in international trade. To measure the degree of competition I calculate a Herfindahl-Hirschman Index $H H I=\sum_{i=1}^{N} s_{i}$, where $s_{i} \in(0,1)$ is firm $i$ 's output market share at the 5-digit industry level. Ownership structure is measured as the share of state ownership at the 3-digit industry level. ${ }^{4}$ Unfortunately, I do not observe ownership at the firm level and therefore cannot estimate the model separately for state and private firms. While international trade operations are observed at the firm level, I only have data for the last year in the sample, 1998. The same applies to the variables measuring the extent of non-monetary transactions at the firm level. Table 3 summarizes additional data on the concentration measures, ownership structure and international trade involvement, as well as the extent of non-monetary transactions in each of the 2-digit industries. Below, I provide a brief

\footnotetext{
${ }^{3}$ I am grateful to the anonymous referee and the co-editor at the Journal of Economics and Management Strategy for pointing this out. While I cannot identify state-owned firms at the firm level, I provide a descriptive analysis of the relationship between the degree of state ownership at the 3-digit industry level and financial constraints on investment in Section 5.

${ }^{4}$ These data are from a different source - a private stock exchange trader PFTS.
} 
discussion of the relevant variables.

Table 3: Summary statistics for HHI, state share, export/import and barter transactions

\begin{tabular}{lcccccc}
\hline & HHI & State share & \multicolumn{4}{c}{ Shares of output in 1998 of } \\
\cline { 5 - 7 } & (5-digit) & (3-digit) & Export & Import & GTRM & Barter \\
\hline \hline Electricity & 0.32 & 0.84 & 0.02 & 0.02 & 0.54 & 0.35 \\
Ferrous metallurgy & 0.55 & 0.43 & 0.24 & 0.06 & 0.19 & 0.30 \\
Chemical & 0.53 & 0.31 & 0.11 & 0.13 & 0.08 & 0.28 \\
Machinery & 0.33 & 0.37 & 0.10 & 0.13 & 0.05 & 0.30 \\
Woodworking & 0.19 & 0.40 & 0.06 & 0.05 & 0.04 & 0.29 \\
Construction materials & 0.39 & 0.29 & 0.05 & 0.04 & 0.02 & 0.71 \\
Light & 0.34 & 0.16 & 0.58 & 0.50 & 0.59 & 0.27 \\
Food & 0.24 & 0.23 & 0.05 & 0.10 & 0.13 & 0.21 \\
Other (food-processing) & 0.34 & 0.57 & 0.04 & 0.03 & 0.16 & 0.11 \\
\hline \hline
\end{tabular}

Notes: HHI is Herfindahl-Hirschman Index. State share is the share of state ownership in the industry. Export and Import measure the share of trade operations in the total output. GTRM and Barter represent shares of non-monetary transactions in each industry. Data for the variables in the last four columns are available only for 1998.

Ownership and market structure. While the transition to a market-based economy began several years before 1993, at the beginning of the sample period the degree of state ownership in some industries remained very high. For example, state ownership in electricity and power generation was about 84 percent. It is worth noting that over time, state ownership has reduced dramatically. In some industries, the degree of state involvement dropped two or three times over the sample period (e.g., see Figure 1).

The role of state ownership is ambiguous and remains an important empirical question. It is possible that governance problems at the state-owned enterprises may adversely affect returns on capital stock, thus reducing the demand for investment. ${ }^{5}$ The situation with the supply of finance is less clear. While it is true that the Ukrainian government occasionally provided state guarantees on the loans taken by the large industrial producers, this rather applied only to a handful of very large firms. ${ }^{6}$ For the vast majority of the firms, state ownership would rather imply limited or no access to external private finance. Also, it is well documented that during the transition period, the Ukrainian government had to severely ration available resources to provide social subsidies, and it is very unlikely that much of the resources were directed to fixed capital stock. A severe deficit of liquidity had negative effects on the investment in fixed capital and often resulted in wage arrears that

\footnotetext{
${ }^{5}$ I do not observe the firm-level ownership structure. State share is only available at the 3-digit industry level, which prevents me from conducting a separate analysis for state and private firms.

${ }^{6}$ It is worth noting that the state guarantees were also frequently discussed in the context of corruption and money laundering.
} 
could be accumulated over several months. Last but not least, there is a clear reverse causality link due to privatization efforts of the government. It is conceivable that firms that were deemed most profitable were successfully sold to private owners. ${ }^{7}$ Therefore, private ownership may work as a signal of future creditworthiness or better management.

Figure 1: Evolution of state ownership in manufacturing, Ukraine 1993-1998
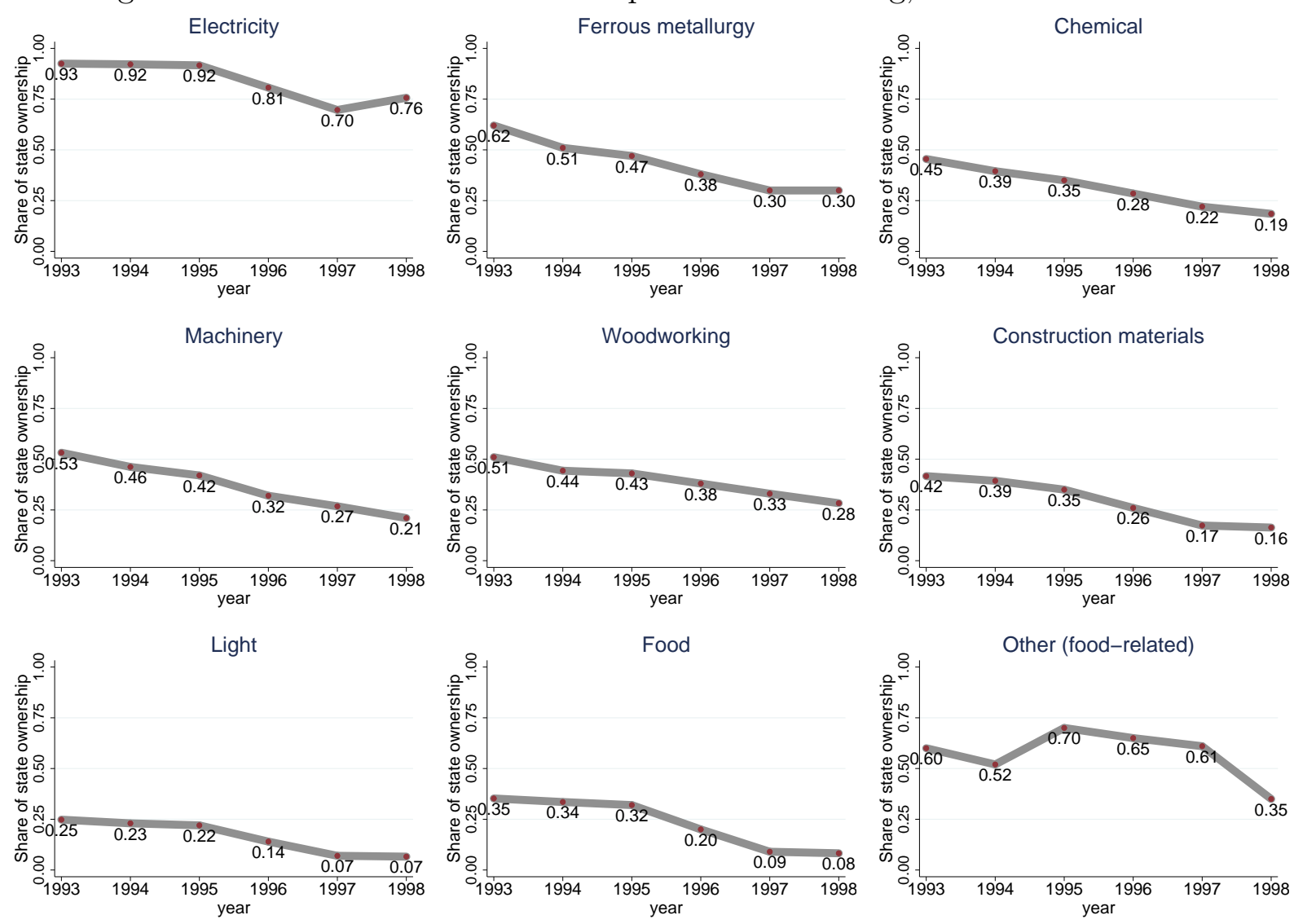

Notes: Each panel illustrates the dynamics of state ownership for 2-digit industry classification used in this study. The raw data used to construct the graphs are not firm-level observations and represent an average share of state firms at the 3-digit industry level.

Another important determinant of returns on fixed capital stock is the degree of market power in each of the industries. Market power allows firms to increase price-cost margins and profits above the competitive level. Even though the structural model assumes that the firms are price takers in both the input and output markets, there is a substantial heterogeneity in the HHI concentration measures across industries. ${ }^{8}$ Therefore, in the

\footnotetext{
${ }^{7}$ This implies that in the post-estimation analysis of the determinants of financial constraints provided in the next sections, coefficients on the ownership controls may not have a structural interpretation.

${ }^{8}$ The price-taking assumption is necessary to represent the firm-level investment problem as a singleagent dynamic programming problem. Substantial market power would require accounting for strategic interaction and estimating a dynamic game, which is computationally too costly.
} 
post-estimation analysis of the characteristics of the constrained firms and industries, I will use the concentration measure among other explanatory variables. Figure 2 illustrates the dynamics of the HHI variable for each industry. While there is some variation in the industries' concentration over time, much larger differences occur across industries.

Figure 2: Evolution of HHI concentration measure, Ukraine 1993-1998
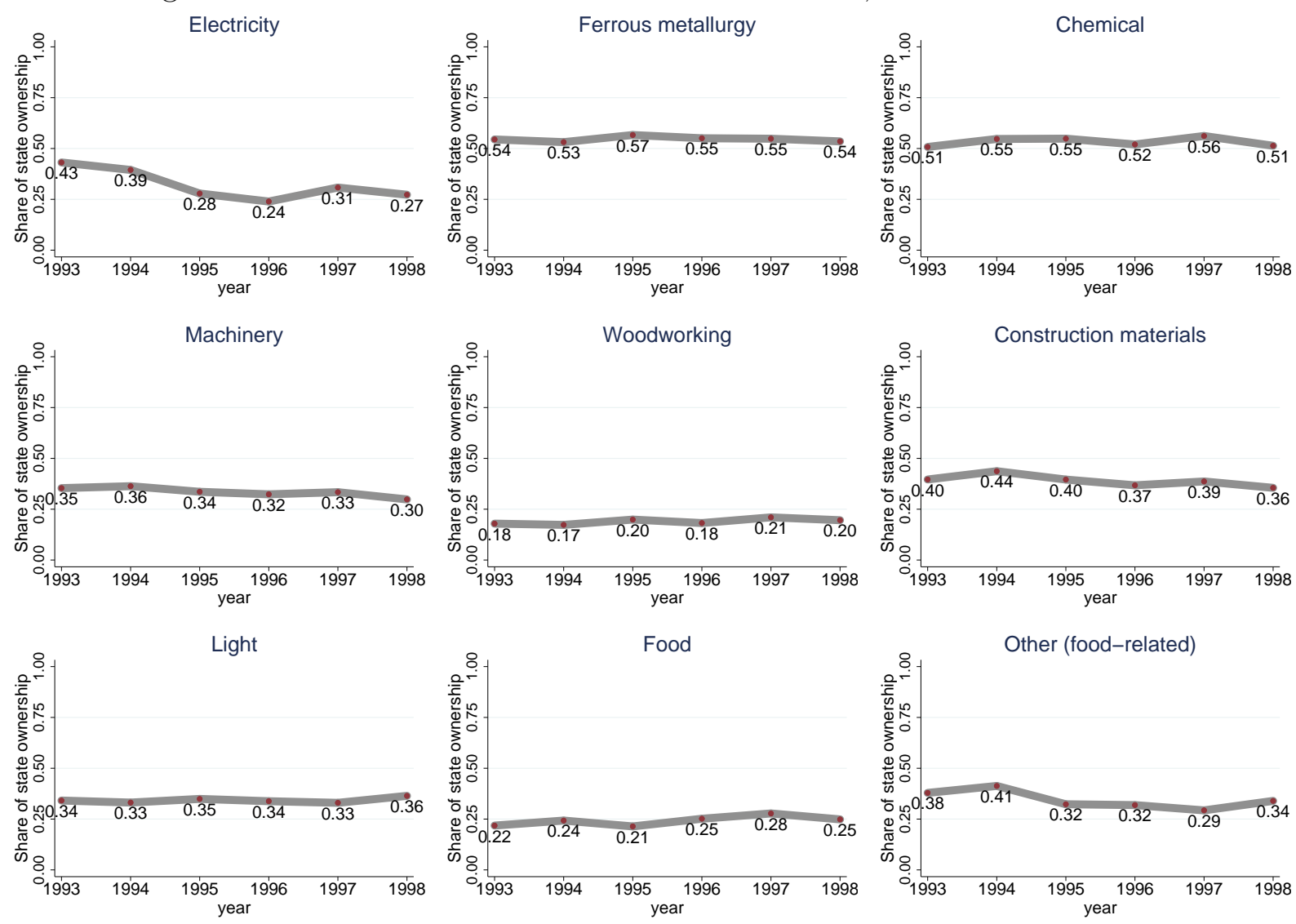

Note: Each panel illustrates the dynamics of the 5-digit HHI concentration measure averaged at the 2-digit industry level.

Liquidity constraints and international trade. In addition, due to liquidity constraints, many of the firms were involved in so-called "non-monetary transactions" of two types. The first type is give-and-take-raw-materials (GTRM) or a toll schema, where a supplier of the intermediate product (typically a foreign firm) supplies the materials in exchange for the final product. ${ }^{9}$ The second type is barter, where firms avoid liquidity constraints by exchanging final products directly. In both cases, the cost of avoiding the liquidity constraints adds up to the total cost of production and may adversely affect

\footnotetext{
${ }^{9}$ Ukrainian legislation requires the customer's raw material to account for not less than $20 \%$ of the total value of the finished product.
} 
firm-level fixed capital investment behavior. One should expect both GTRM and barter to reduce the resources available to the firms due to higher transaction costs for those involved. However, if the liquidity constraints are expected to go away in the long run, their effect on the firms' continuation value is less important, i.e., the demand for the investment good may stay relatively high, while firms' own resources are consumed by the transaction costs, making firms more likely to borrow externally.

The effect of exposure to international trade is more ambiguous. Significant depreciation of the national currency during the transition period clearly put exporters into an advantaged position over firms selling domestically, and particularly those conducting import transactions. Exposure to the international markets can also translate into the differences in the level and variation of cash flow variables between exporting and non-exporting firms, e.g., cash flow variables for domestically and internationally trading firms may be negatively correlated. It is reasonable to expect that an exporting firm ceteris paribus should have access to more markets (domestic and international) and larger markets for its products, lower production costs due to changes in the exchange rate, and subsequently higher demand for the investment good. Supposedly higher demand for the investment good can be matched by better access to liquidity for the exporters, in which case the firms can still finance their desired investment by using retained earnings. However, if the demand for the investment good is too high, it may require firms to borrow, which may not always be possible.

For the importing firms, depreciation of the national currency most likely had an adverse effect on production costs. However, access to foreign markets may also mean more transparent accounting and better access to external finance (domestically or abroad). ${ }^{10}$ It is worth noting that GTRM transactions are more likely to occur between an importing firm and its foreign counterpart; hence, the import may have a dual impact on the firms' investment: directly and through non-monetary transactions. Therefore, the effect of export and import operations for the firm-level fixed capital investment remains an important empirical question, which I address in this study.

\footnotetext{
${ }^{10}$ It is worth noting that while currencies of all the Commonwealth of Independent States (CIS) countries experienced a dramatic depreciation relative to the U.S. dollar, there were substantial differences in relative depreciation rates of the individual currencies. Historically, Ukraine has had very tight trade connections with Russia.
} 


\section{Theoretical model}

The motivation behind the methodology suggested in this section can be summarized by a citation from Greenwald et al. (1984): "In some circumstances, [...] it is the availability of capital and not its cost that determines the level of investment." (p.198) Consider an $N$-firms industry, where firms are indexed by $i=1, \ldots, N$. Time is discrete and indexed by $t=0,1, \ldots, \infty$. The firms are assumed to maximize the net present value of future cash flows over an infinite time horizon by choosing various factors of production, e.g., labor, capital, raw materials, etc. Let $\Pi\left(A_{i t}, K_{i t}, I_{i t}\right)$ denote the per-period reward function, which depends on the current period productivity of capital (or demand shock), $A_{i t}$, the level of own capital stock, $K_{i t} \in \mathbb{R}_{+}$, and the current period investment, $I_{i t}$. Then, firm $i$ 's maximization problem can be written as

$$
\begin{gathered}
V\left(A_{i 0}, K_{i 0}\right) \equiv \max _{I_{i 0}, I_{i 1}, \ldots} \mathbb{E}\left[\sum_{t=0}^{\infty} \beta^{t} \Pi\left(A_{i t}, K_{i t}, I_{i t}\right),\right] \\
\text { s.t. : } I_{i t} \geq 0, \forall t, \\
A_{i t+1} \stackrel{i i d}{\sim} F\left(\cdot \mid A_{i t}\right), \\
K_{i t+1}=\delta K_{i t}+I_{i t},
\end{gathered}
$$

where $\delta \in(0,1)$ and $\beta \in(0,1]$ are common to all firms' depreciation rate and discount factor, respectively. Gross investment, $I_{i t}$, occurs at the beginning of each period and it takes one period to order, deliver and install new capital, i.e., it takes exactly one period before investment becomes productive. The one-period delay in investment efficiency is consistent with the general framework in Ericson and Pakes (1995).

Assume all factors of production are costlessly adjustable, except for capital stock. Then recursive formulation of the infinite horizon dynamic programming problem can be 
written as

$$
\begin{aligned}
V^{u}\left(A_{i t}, K_{i t}\right)= & \max _{I_{i t}}\left\{\Pi\left(A_{i t}, K_{i t}, I_{i t}\right)+\beta \mathbb{E}\left[V^{u}\left(K_{i t+1}, A_{i t+1}\right) \mid I_{i t}, K_{i t}, A_{i t}\right]\right\} \\
& \text { s.t. : } \\
& 0 \leq I_{i t} \\
& A_{i t+1} \stackrel{i i d}{\sim} F\left(\cdot \mid A_{i t}\right) \\
& K_{i t+1}=\delta K_{i t}+I_{i t} .
\end{aligned}
$$

Equations (1a) through (1d) describe the dynamic programming problem of a firm that can borrow. ${ }^{11}$ With some abuse of terminology I would refer to this problem as an unconstrained maximization problem. As discussed above, in Ukraine firms faced substantial information asymmetries and often had no access to external funds. These firms solve a constrained dynamic programming problem defined below,

$$
\begin{aligned}
V^{c}\left(A_{i t}, K_{i t}\right)= & \max _{I_{i t}}\left\{\Pi\left(A_{i t}, K_{i t}, I_{i t}\right)+\beta \mathbb{E}\left[V^{c}\left(K_{i t+1}, A_{i t+1}\right) \mid I_{i t}, K_{i t}, A_{i t}\right]\right\} \\
& \text { s.t. : } \\
& 0 \leq I_{i t} \leq \pi\left(A_{i t}, K_{i t}\right) \\
& A_{i t+1} \stackrel{i i d}{\sim} F\left(\cdot \mid A_{i t}\right) \\
& K_{i t+1}=\delta K_{i t}+I_{i t} .
\end{aligned}
$$

Note that the difference between equations (1a)-(1d) and (2a)-(2d) is in the restrictions (1b) and $(2 \mathrm{~b})$, where there is no upper bound on investment in the unconstrained formulation and the maximum investment is capped from above by the per-period profit function $\pi\left(A_{i t}, K_{i t}\right)$. Assume that the per-period profit function is linear in capital, i.e.,

$$
\pi\left(A_{i t}, K_{i t}\right)=A_{i t} K_{i t},
$$

and that firms face a quadratic adjustment cost function that depends on both the level

\footnotetext{
${ }^{11}$ Note that constraints (1d) and (2d) are not the same as in Bond and Meghir (1994), where investment occurs at the beginning of each period and immediately becomes productive. The latter helps in deriving a linear Euler equation but appears less realistic.
} 
of capital stock and the level of investment,

$$
C\left(K_{i t}, I_{i t}\right)=\frac{1}{2} b K_{i t}\left(\frac{I_{i t}}{K_{i t}}\right)^{2},
$$

where $b \geq 0$ is a parameter capturing the cost of adjustment. Then, the per-period reward function for firm $i$ in period $t$ can be written as

$$
\Pi\left(A_{i t}, K_{i t}, I_{i t}\right)=A_{i t} K_{i t}-p_{t} I_{i t}-\frac{1}{2} b K_{i t}\left(\frac{I_{i t}}{K_{i t}}\right)^{2},
$$

where $p_{t}$ is the price of the investment good.

In each time period a firm can be in one of the two mutually exclusive and exhaustive regimes: (1) unconstrained and (2) constrained. I assume that each firm is fully aware of the regime it is operating in and that the firm believes that the regime is not going to change. In other words, firms that were able to borrow will continue to be able to rely on external sources of financing their investment, while the firms that had to rely on their own means will face borrowing constraints in the future.

\subsection{Policy functions}

Consider solutions to the maximization problems for the firms operating in constrained and unconstrained regimes. Let $I^{u}\left(A_{i t}, K_{i t}\right)$ and $I^{c}\left(A_{i t}, K_{i t}\right)$ denote solutions to the dynamic problems (1a)-(1d) and (2a)-(2d), respectively. There are two ways in which policy functions of the constrained and unconstrained firms may differ. First, the constraint in equation (2b) suggests lower levels of investment in some states (i.e., when the constraint is binding), which would slow down capital accumulation in the long run. Second, for some states there are dynamic incentives for the constrained firms to over-invest relative to the unconstrained optimal investment function. For example, larger investment today not only increases firms' continuation value due to higher capital stock, but it also reduces the probability of binding constraint on investment in the future periods. Figure 3 illustrates potential differences in the optimal investment functions and the implied long-run capital evolution. 
Figure 3: Example of optimal policy and long-run capital evolution
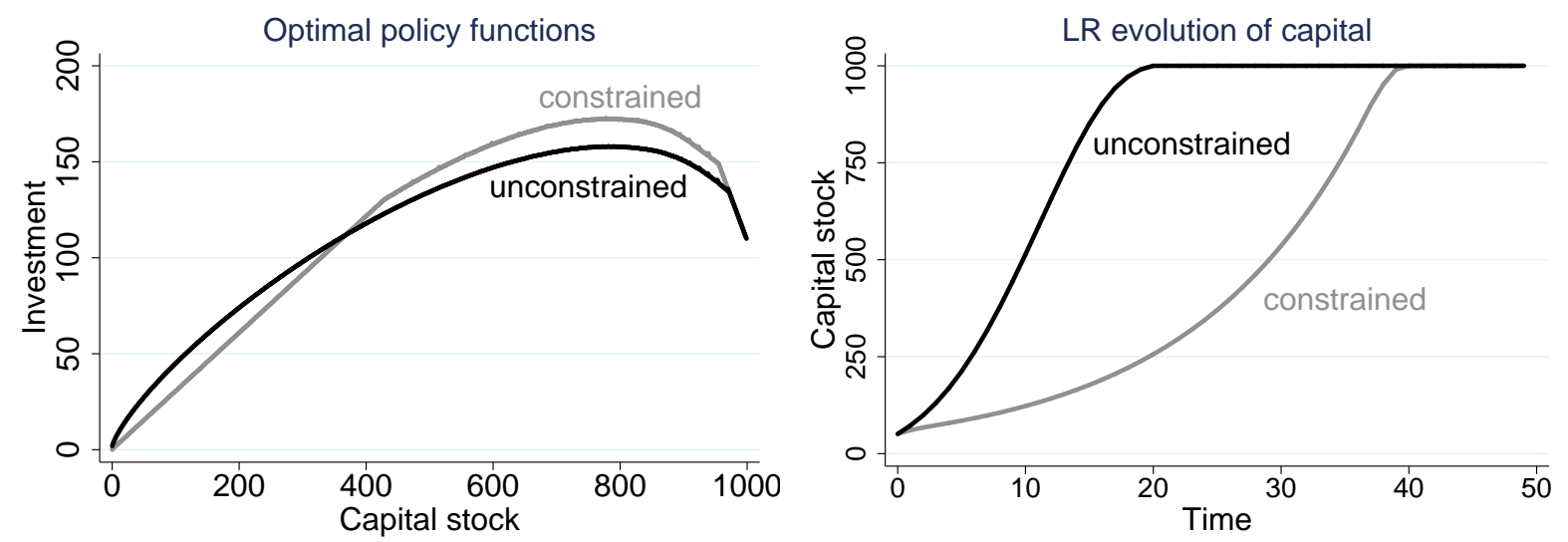

Notes: The left panel illustrates optimal policy for the firms operating in constrained and unconstrained regimes as a function of capital stock for fixed value of the state variable $A$; the right panel illustrates long-run capital evolution resulting if the firms follow their optimal policies.

In the data, I observe realized investment $I_{i t}^{o}$, which is given by

$$
I_{i t}^{o}=\left\{\begin{array}{l}
I^{u}\left(A_{i t}, K_{i t}\right) \text { if } i \text { operates in an unconstrained regime, } \\
I^{c}\left(A_{i t}, K_{i t}\right) \text { if } i \text { operates in a constrained regime. }
\end{array}\right.
$$

Unfortunately, there is no direct data on whether a firm has access to external finance. However, in addition to the investment level, I also observe firms' profits, $\pi_{i t}=\pi\left(A_{i t}, K_{i t}\right)=A_{i t} K_{i t}$. Given the observed investment level, reported profits and parameters, it is possible to infer whether $\Pi\left(A_{i t}, K_{i t}, I_{i t}\right)$ is negative, in which case the firm should have been able to borrow. Then, observed investment in equation (6) can be augmented by a selection equation as follows,

$$
I_{i t}^{o}= \begin{cases}I^{u}\left(A_{i t}, K_{i t}\right) & \text { if } \Pi\left(A_{i t}, K_{i t}, I_{i t}^{o}\right)<0, \\ I^{c}\left(A_{i t}, K_{i t}\right) & \text { if } \Pi\left(A_{i t}, K_{i t}, I_{i t}^{o}\right) \geq 0\end{cases}
$$

where the firms operating in an unconstrained investment regime are identified by the negative value of the net per-period reward function, $\Pi\left(A_{i t}, K_{i t}, I_{i t}\right)<0$, which (by assumption) can only happen if the firm can borrow. ${ }^{12}$ It also follows that if the implied per-period reward function is always positive, i.e., the firm always invests a feasible amount

\footnotetext{
${ }^{12}$ Note that the classification of firms is strict, while in an earlier version of this paper I used stochastic classification within a more reduced-form regime switching regression analysis. While it is possible to add stochastic elements to the classification, it would increase the set of parameters to estimate and the resulting computational burden.
} 
given its own resources, such a firm would be classified as operating in a constrained regime, which seems to be an accurate representation of the economic situation in Ukraine in 1993-1998.

To provide reduced-form evidence for the presence of financial constraints, I derive an empirical Euler equation for the unconstrained dynamic programming problem. Let $\left\{I_{i t}^{*}\right\}_{t=0}^{\infty}$ denote an optimal program solving equation (1a) subject to constraints (1b), (1c) and (1d) and consider an alternative program defined as

$$
I_{i t}^{a}=\left\{\begin{array}{l}
I_{i t}^{a}=I_{i t}^{*}+\epsilon, \\
I_{i t+1}^{a}=I_{i t+1}^{*}-\delta \epsilon, \\
I_{i t+\tau}^{a}=I_{i t}^{*}, \tau \geq 2 .
\end{array}\right.
$$

Note that the alternative program resets perturbed capital stock at the beginning of period $t+2$ to the level of capital stock under the original optimal program, i.e.,

$$
\begin{aligned}
K_{i t+2}^{a} & =\delta K_{i t+1}^{a}+I_{i t+1}^{a} \\
& =\delta\left(\delta K_{i t}+I_{i t}^{a}\right)+I_{i t+1}^{a} \\
& =\delta^{2} K_{i t}+\delta I_{i t}^{*}+\delta \epsilon+I_{i t+1}^{*}-\delta \epsilon \\
& =\delta^{2} K_{i t}+\delta I_{i t}^{*}+I_{i t+1}^{*}=K_{i t+2}^{*} .
\end{aligned}
$$

Therefore, the difference between the value functions under the optimal program and under the alternative program can be expressed as the difference between the per-period payoff function in the first two periods. In particular,

$$
\left\{\begin{array}{l}
V^{*}\left(A_{i t}, K_{i t}\right)=\Pi\left(A_{i t}, K_{i t}, I_{i t}^{*}\right)+\beta \mathbb{E}\left[\Pi\left(A_{i t+1}, K_{i t+1}^{*}, I_{i t+1}^{*}\right)+\beta^{2} V^{*}\left(A_{i t+2}, K_{i t+2}^{*}\right)\right] \\
V^{a}\left(A_{i t}, K_{i t}\right)=\Pi\left(A_{i t}, K_{i t}, I_{i t}^{a}\right)+\beta \mathbb{E}\left[\Pi\left(A_{i t+1}, K_{i t+1}^{a}, \tilde{I}_{i t+1}\right)+\beta^{2} V^{*}\left(A_{i t+2}, K_{i t+2}^{*}\right)\right]
\end{array}\right.
$$




$$
\begin{aligned}
\Longrightarrow \Delta(\epsilon) & =V^{*}\left(A_{i t}, K_{i t}\right)-V^{a}\left(A_{i t}, K_{i t}\right) \\
& =\Pi\left(A_{i t}, K_{i t}, I_{i t}^{*}\right)+\beta \mathbb{E}\left[\Pi\left(A_{i t+1}, \delta K_{i t}+I_{i t}^{*}, I_{i t+1}^{*}\right)\right] \\
& -\Pi\left(A_{i t}, K_{i t}, I_{i t}^{a}\right)-\beta \mathbb{E}\left[\Pi\left(A_{i t+1}, \delta K_{i t}+I_{i t}^{a}, I_{i t+1}^{a}\right)\right] \\
& =\Pi\left(A_{i t}, K_{i t}, I_{i t}^{*}\right)+\beta \mathbb{E}\left[\Pi\left(A_{i t+1}, \delta K_{i t}+I_{i t}^{*}, I_{i t+1}^{*}\right)\right] \\
& -\Pi\left(A_{i t}, K_{i t}, I_{i t}^{*}+\epsilon\right)-\beta \mathbb{E}\left[\Pi\left(A_{i t+1}, \delta K_{i t}+I_{i t}^{*}+\epsilon, I_{i t+1}^{*}-\delta \epsilon\right)\right] .
\end{aligned}
$$

Note that by construction, $\Delta(\epsilon) \geq 0$, and it is minimized at $\epsilon=0$. Therefore,

$$
\left.\frac{\partial \Delta(\epsilon)}{\partial \epsilon}\right|_{\epsilon=0}=0
$$

and

$$
0=-\frac{\partial \Pi\left(A_{i t}, K_{i t}, I_{i t}\right)}{\partial I_{i t}}-\beta \frac{\partial \Pi\left(A_{i t+1}, K_{i t+1}, I_{i t+1}\right)}{\partial K_{i t+1}}+\beta \delta \frac{\partial \mathbb{E} \Pi\left(A_{i t+1}, K_{i t+1}, I_{i t+1}\right)}{\partial I_{i t+1}}
$$

Under the functional form restrictions, equation (8) can be written

$$
0=p_{i t}+b\left(\frac{I_{i t}}{K_{i t}}\right)-\beta \mathbb{E}\left[A_{i t+1}+\frac{1}{2} b\left(\frac{I_{i t+1}}{K_{i t+1}}\right)^{2} \mid \mathcal{I}_{i t}\right]+\beta \delta \mathbb{E}\left[-p_{i t+1}-b \frac{I_{i t+1}}{K_{i t+1}} \mid \mathcal{I}_{i t}\right]
$$

where $\mathcal{I}_{i t}$ denotes the information set for firm $i$ at time $t$, when the investment decision is made.

Assuming rational expectations, we can evaluate equation (9) at the realized future values of the capital productivity, $A_{i t+1}$, future investment prices, $p_{i t+1}$, investment level, $I_{i t+1}$, and resulting capital stock, $K_{i t+1}$. Following the intuition from Hansen and Singleton (1982), by rearranging equation (9), I can define a relationship between the current period observable variables, their future values, and an error term, $\varepsilon_{i t}$, such that

$$
\frac{1}{2}\left(\frac{I_{i t+1}}{K_{i t+1}}\right)^{2}+\delta\left(\frac{I_{i t+1}}{K_{i t+1}}\right)=\frac{p_{i t}-\beta A_{i t+1}-\beta \delta p_{i t+1}}{\beta b}+\frac{1}{\beta}\left(\frac{I_{i t}}{K_{i t}}\right)+\varepsilon_{i t} .
$$

Let $y_{i t+1} \equiv \frac{1}{2}\left(\frac{I_{i t+1}}{K_{i t+1}}\right)^{2}+\delta\left(\frac{I_{i t+1}}{K_{i t+1}}\right), \alpha_{0 t} \equiv \frac{p_{i t}-\beta A_{i t+1}-\beta \delta p_{i t+1}}{\beta b}, \alpha_{1} \equiv \frac{1}{\beta}$, and $i_{i t}=$ 
$\left(\frac{I_{i t}}{K_{i t}}\right)$. Then, the empirical Euler equation can be expressed as follows,

$$
y_{i t+1}=\alpha_{0 t}+\alpha_{1} i_{i t}+\epsilon_{i t}
$$

where the optimization error must satisfy the following conditional independence restriction,

$$
E\left[\varepsilon_{i t} \mid \mathcal{I}_{i t}\right]=0
$$

It is clear that under this assumption equation (10) can be estimated using ordinary least squares (OLS).

Without borrowing constraints, any such variable should not have a significant impact on the future investment, i.e., in an augmented investment equation,

$$
y_{i t+1}=\alpha_{0 t}+\alpha_{1} i_{i t}+\alpha_{2} C F_{i t}+\epsilon_{i t},
$$

estimates of the parameter $\alpha_{2}$ should not be statistically significantly different from zero. However, when the constraint binds, for example when a firm cannot access external funds due to the asymmetric information problem between the borrower and lender, the firm has to rely on its own means to finance its investment. As a result, variables measuring its own financial resources may become significant determinants of the observed investment levels. Profit-to-capital, sales-to-capital and output-to-capital ratios are used as proxy variables for the per-period cash flow.

There is a small complication with equation (12), where the right-hand side depends on $\delta$, which is equal to 1 minus the depreciation rate of the capital. This complication is not present in the Hansen and Singleton (1982) formulation because they assume that invested capital becomes immediately productive. This paper more realistically assumes that it takes one period to order, deliver and install new capital, and therefore I must obtain an estimate of $\delta$ to construct the dependent variable. Luckily, in the data firms often report depreciation rates (though with many missing values). The estimates of $\delta$ are very similar to those obtained in the structural model and reported in Table 5 in Section 5 (row 1-depr., $\delta$ ) with correct standard errors from the joint GMM estimation. 
Table 4: Reduced-form evidence of financial constraints, Ukraine 1993-1998

\begin{tabular}{lcccccc}
\hline & $(1)$ & $(2)$ & $(3)$ & $(4)$ & $(5)$ & $(6)$ \\
\hline Constant & 0.001 & -0.046 & -0.034 & $-0.103^{* * *}$ & $-0.101^{* * *}$ & -0.049 \\
& $(0.036)$ & $(0.036)$ & $(0.035)$ & $(0.035)$ & $(0.035)$ & $(0.036)$ \\
$I_{i t} / K_{i t}$ & $0.626^{* * *}$ & $1.124^{* * *}$ & $1.093^{* * *}$ & $1.100^{* * *}$ & $1.099^{* * *}$ & $1.099^{* * *}$ \\
& $(0.024)$ & $(0.031)$ & $(0.031)$ & $(0.031)$ & $(0.031)$ & $(0.032)$ \\
\hline$\pi_{i t} / K_{i t}$ & & $0.023^{* * *}$ & & & $0.017^{* * *}$ & \\
& & $(0.002)$ & & & $(0.004)$ & \\
Salesit $_{\text {It }}$ & & & 0.000 & & -0.000 & \\
& & & $(0.000)$ & & $0.000)$ & \\
Output $_{i t} / K_{i t}$ & & & & $0.015^{* * *}$ & $0.013^{* * *}$ & \\
& & & & $(0.001)$ & $(0.001)$ & \\
\hline
\end{tabular}

$\pi_{i t} / K_{i t} \times$ industry

Electricity

Ferrous metallurgy

Chemical

Machinery

Woodworking

Construction

Light

Food processing

Other agriculture

\begin{tabular}{lcccccc}
\hline Year dummies & yes & yes & yes & yes & yes & yes \\
Industry dummies & yes & yes & yes & yes & yes & yes \\
\hline Observations & 29,671 & 29,505 & 29,603 & 29,613 & 29,470 & 29,505 \\
R-squared & 0.028 & 0.049 & 0.046 & 0.054 & 0.054 & 0.055 \\
\hline
\end{tabular}

Notes: The dependent variable $y_{i t}=\frac{1}{2}\left(\frac{I_{i t+1}}{K_{i t+1}}\right)^{2}+\delta\left(\frac{I_{i t+1}}{K_{i t+1}}\right)$. All specifications use OLS. Standard errors are in parentheses: ${ }^{* * *} \mathrm{p}<0.01,{ }^{* *} \mathrm{p}<0.05,{ }^{*} \mathrm{p}<0.1$. Results illustrate that various measures of cash flows have positive coefficients in the empirical Euler equation (12). IV versions of regressions in columns (2) through (5) are presented in Appendix A.2 in Table 10.

Table 4 summarizes results from several specifications based on equation (12). Param- 
eter estimates for alternative measures of per-period cash flows such as profits, sales and outputs typically have a positive and statistically significant effect on the firms' investment behavior.

Results for another exercise with the empirical Euler equation are reported in Appendix A. In these regressions, firms with positive observed investment levels were divided into low-profitable and high-profitable groups with the profitability measure defined as $\pi_{i t} / K_{i t}$. Each group is determined by the highest (lowest) quintile or tertile of the distribution. The importance of the financial constraints should be reflected in the magnitudes, signs and statistical significance of the coefficients on the cash flow proxy variables. In particular, low-profitability firms are much more likely to borrow in order to finance their investment, while the firms with high profitability of capital can invest more by redirecting their profits to investment. In other words, financially constrained firms with higher current profits should also have larger investments, while this link is expected to be weaker for the firms using a combination of their own and external finances.

Table 9 in Appendix A.1 reports coefficients on several proxy variables for the current period cash flow. As expected, investment activity is increasing in profits and output levels normalized by capital stock. Coefficients on these variables are bigger and are estimated more precisely (they have smaller standard errors) for the firms whose own resources are relatively large. For the subset of firms with relatively low profits in the current period, the relationship between cash flows and investment levels is much weaker. ${ }^{13}$ This finding is supported by the joint significance test for all of the available cash flow variables. For high-current profit firms the coefficients are statistically significant at any level of significance, while for the firms with smaller current profit levels the null cannot be rejected at the 1 percent level.

It is worth noting that there is an important caveat to these arguments. Additional cash flow variables included in the Euler equation may indeed contain relevant information about investment attractiveness of the firm. For example, current period cash flows may be affected by adjustment cost shocks, and the same shock would affect the investment choice. If present, such an endogeneity problem would require instrumental variables that affect cash flow variables and are uncorrelated with the current period innovations.

To address the endogeneity problem, I experiment with instrumenting three proxy

\footnotetext{
${ }^{13} \mathrm{~A}$ somewhat puzzling finding is that sales-to-capital ratio, when included together with other cash flow proxy variables, has either an insignificant positive or a statistically significant negative coefficient.
} 
variables for cash flow, $\pi_{i t} / K_{i t}$, Sales ${ }_{i t} / K_{i t}$ and Output ${ }_{i t} / K_{i t}$, with their own lagged values. In Appendix A.2 in Table 10, I re-estimate specifications (2) through (5) using firms' own one-period-lagged values of the cash flow variables. The key takeaway is that cash flow variables remain statistically significant and have a positive effect on investment. If only one of the proxy variables is included, it is always positive and statistically significant in IV specifications. When all of them are included at the same time, only output per capital stock is statistically significant. The finding that parameter estimates for the cash flow proxy variables have positive signs and are statistically significant at conventional significance levels is consistent with the presence of financial constraints in the Ukrainian economy.

\section{Empirical specification}

In the data, I observe investment levels $I_{i t}^{o}$, which may be described as the optimal solution to the dynamic programming problem with or without financial constraints on investment as defined by equation (7). Given the economic situation in Ukraine in 1993-1998, it is conceivable that the majority of firms could have difficulties accessing external resources for their fixed capital investment. However, it would be incorrect to assume that every firm can only rely on their internal resources. For example, in the data we observe firms reporting zero or very low levels of profit and large fixed capital investment at the same time. These firms are likely to be able to borrow.

To estimate model parameters I use a simulated method of moments that relies on the following empirical specification. First, I define a disturbance term $\epsilon_{i t}$, which accounts for the approximation error in the optimal policy functions. In particular, let

$$
\begin{aligned}
\epsilon_{i t}= & \mathbb{1}\left\{\Pi\left(A_{i t}, K_{i t}, I_{i t}^{o} ; \theta\right)<0\right\}\left(I_{i t}^{o}-I^{u}\left(A_{i t}, K_{i t} ; \theta\right)\right) \\
& +\mathbb{1}\left\{\Pi\left(A_{i t}, K_{i t}, I_{i t}^{o} ; \theta\right) \geq 0\right\}\left(I_{i t}^{o}-I^{c}\left(A_{i t}, K_{i t} ; \theta\right)\right),
\end{aligned}
$$

where $\mathbb{1}\{\cdot\}$ is an indicator function, $I_{i t}^{o}$ is the investment level observed in the data, $\theta$ is a vector of structural parameters and $I^{u}\left(A_{i t}, K_{i t} ; \theta\right)$ and $I^{c}\left(A_{i t}, K_{i t} ; \theta\right)$ are policy functions solving the dynamic programming problems of firms with and without access to external funds as described by (1a)-(1d) and (2a)-(2d), respectively. This error term has no structural interpretation, i.e., at the time when firms decide on their investment, expectation 
of this error is zero. In other words, I make the following identifying assumption.

Assumption 1: The approximation error in equation (13) satisfies

$$
\mathbb{E}\left[\epsilon_{i t} \mid \mathcal{I}_{i t}\right]=0,
$$

where $\mathcal{I}_{\text {it }}$ is firm i's information set at time $t$.

Consistent with Assumption 1, I use $K_{i t}, A_{i t}$ and several alternative cash flow proxy variables such as profits, sales and outputs to form orthogonality restrictions for estimation.

Values of the state variable $A_{i t}$ are obtained using reported profits and the functional form restriction (3). Using the data on marginal profitability of capital, I estimate reduced form coefficients in the firms' beliefs under the assumption that they evolve as the following $\mathrm{AR}(1)$ process.

Assumption 2: Firms' beliefs about future values of the exogenous stochastic variable $A_{i t}, F\left(A_{i t+1} \mid A_{i t}\right)$, in the law of motion in equations (1c) and (2c) are given by the following $A R(1)$ specification,

$$
A_{i t}=\gamma_{0}+\gamma_{1} A_{i t-1}+\nu_{i t} \sigma_{\nu}
$$

where $\gamma_{0}, \gamma_{1}$ and $\sigma_{\nu}$ are parameters of the firms' belief specification and $\nu_{i t} \stackrel{i i d}{\sim} N(0,1)$.

To estimate parameters of the model I use the nested fixed-point algorithm. In the inner loop, given parameter values, I solve the dynamic programming problem (1a) subject to constraints (1b)-(1d) and the dynamic programming problem (2a) subject to constraints (2b)-(2d). To solve the Bellman equations I keep state variables continuous and solve for the policy and value functions at a finite set of points in the state space: for $A_{i t} \mathrm{I}$ use 50 grid points and for $K_{i t}$ I use 2,000 grid points. Whenever future values of the state variables land between the grid points, two-dimensional linear interpolation is employed.

In the outer loop, solutions to the constrained and unconstrained maximization problems are then matched with the data via the random error term defined in equation (13). This is done by constructing sample analogs of the population moment conditions based on Assumption 1. In particular, the main specification uses the following moment conditions,

$$
G_{N}(\theta)=\frac{1}{N} \sum_{i=1}^{N} g_{i}(\theta), \quad g_{i}(\theta)=\epsilon_{i}(\theta) \times x_{i}, \quad x_{i}=\left(1, K_{i}, \pi_{i}\right)
$$


where $i$ denotes an observation. Estimation is performed using two-stage optimal GMM

$$
\hat{\theta}=\underset{\theta}{\arg \min } G_{N}(\theta)^{\prime} \cdot W \cdot G_{N}(\theta)
$$

with the first stage weighting matrix, $W$, given by $\left(X^{\prime} X\right)^{-1}$ (optimal for linear models) and the second stage weighting matrix based on the variances of the moment conditions, $\left(g_{i}(\theta)^{\prime} g_{i}(\theta)\right)^{-1}$.

\section{Estimation results}

Estimation results obtained from the second step of a two-stage optimal GMM algorithm are reported in Table 5 below. The first stage and continuously updated GMM estimates can be found in Appendix C in Table 13 and Table 14, respectively.

Table 5: Estimates of structural parameters, Ukraine manufacturing, 1993-1998

\begin{tabular}{lccccccccc}
\hline & Electr. & $\begin{array}{c}\text { Ferr. } \\
\text { met. }\end{array}$ & Chemic. & Machin. & $\begin{array}{c}\text { Wood- } \\
\text { working }\end{array}$ & $\begin{array}{c}\text { Constr. } \\
\text { mat. }\end{array}$ & Light & Food & Other \\
\hline \hline Adj.cost., $b$ & 7.562 & 35.897 & 26.228 & 23.703 & 8.073 & 9.005 & 13.665 & 14.163 & 29.736 \\
(s.e.) & $(1.088)$ & $(2.457)$ & $(3.120)$ & $(0.505)$ & $(0.295)$ & $(1.656)$ & $(0.964)$ & $(3.665)$ & $(3.817)$ \\
Inv.price, $p_{I}$ & 0.879 & 0.963 & 0.943 & 0.534 & 1.425 & 0.464 & 1.469 & 2.075 & 2.143 \\
(s.e.) & $(0.043)$ & $(0.065)$ & $(0.094)$ & $(0.067)$ & $(0.045)$ & $(0.020)$ & $(0.067)$ & $(0.200)$ & $(0.290)$ \\
1-depr., $\delta$ & 0.905 & 0.928 & 0.915 & 0.908 & 0.908 & 0.892 & 0.907 & 0.904 & 0.900 \\
(s.e.) & $(0.002)$ & $(0.002)$ & $(0.002)$ & $(0.001)$ & $(0.002)$ & $(0.001)$ & $(0.001)$ & $(0.001)$ & $(0.001)$ \\
\hline Pr(unc) & 0.60 & 0.25 & 0.27 & 0.23 & 0.26 & 0.30 & 0.23 & 0.26 & 0.15 \\
\hline E[I(con)] & 52.45 & 63.46 & 13.78 & 4.71 & 2.97 & 2.36 & 1.97 & 3.86 & 1.67 \\
E[I(obs)] & 106.64 & 85.80 & 21.41 & 5.91 & 3.89 & 3.28 & 2.55 & 4.97 & 2.21 \\
E[I(unc)] & 113.56 & 91.87 & 24.08 & 6.93 & 4.03 & 3.26 & 2.67 & 5.03 & 2.19 \\
\hline Num. obs. & 2,417 & 883 & 1,060 & 9,433 & 2,451 & 4,506 & 3,036 & 10,307 & 4,378 \\
Stg.2 f-val. & 0.258 & 0.411 & 0.053 & 2.625 & 1.038 & 1.777 & 1.893 & 7.366 & 3.182 \\
p(J-stat) & $(0.61)$ & $(0.52)$ & $(0.82)$ & $(0.11)$ & $(0.31)$ & $(0.18)$ & $(0.17)$ & $(0.01)$ & $(0.07)$ \\
\hline \hline
\end{tabular}

Notes: All specifications are estimated using the two-step GMM. Standard errors are in parentheses. Parameter $\delta$ is equal to 1-depreciation rate of capital. $\operatorname{Pr}(u n c)$ reports the average probability that firms have access to external funds, i.e., can borrow. $\mathbb{E}\left[I_{i t}^{c}\right], \mathbb{E}\left[I_{i t}^{o}\right]$ and $\mathbb{E}\left[I_{i t}^{u}\right]$ report the industry average for constrained, observed and unconstrained investment levels, respectively. $\mathrm{p}(\mathrm{J}$-stat $)$ reports the p-value of Hansen's J-statistic for the 2-step optimal GMM.

Each column of Table 5 represents a 2-digit industry. The top panel of the table lists estimates of structural parameters and standard errors. The average probability of an 
unconstrained investment regime is reported in the row denoted $\operatorname{Pr}($ unc). The following three rows labeled $\mathbb{E}[\mathrm{I}(\mathrm{con})], \mathbb{E}[\mathrm{I}(\mathrm{obs})]$ and $\mathbb{E}[\mathrm{I}($ unc $)]$ present average constrained, average observed and average unconstrained investment, respectively. ${ }^{14}$

All structural parameter estimates are statistically significant. The Hansen overidentifying restriction test is reported in the line "stg. $2 \mathrm{f}$-val." with the p-value given in the row labeled $\mathrm{p}(\mathrm{J}$-stat $)$. The model is not rejected for all industries at conventional significance levels of 5 percent. The only exception is the food industry, which has the lowest p-value of 0.01 .

According to the estimates, the ferrous metallurgy, other food-related and chemical industries, followed by machinery, have the highest adjustment cost parameters. The lowest adjustment cost parameters are estimated for electricity generation, woodworking and construction materials. The price of an investment good is estimated to be lowest for construction materials and machinery and the highest for food and food-related industries. The highest depreciation rate is estimated for construction materials, followed by other food-related industry. The lowest depreciation rates are found for the ferrous metallurgy and chemical industries. The results suggest that observed firm-level investments are rather close to the unconstrained levels. On average, the probability of an unconstrained regime (that is, the ability to borrow from external sources) varies between 0.6 for electricity generation and 0.15 for the other food-related industry. For the rest of the industries, the probability of having access to external finance varies between 0.23 and 0.30 . Figure 4 illustrates average levels of observed investment and constrained and unconstrained predictions. Despite the high probability of operating in a constrained regime, on average, observed investment levels are close to the unconstrained predictions.

\footnotetext{
${ }^{14}$ Constrained and unconstrained investments are calculated for each observation and represent two possible/counterfactual regimes, while observed investment is factual.
} 
Figure 4: Average unconstrained, observed and constrained investment, Ukraine 1993-1998

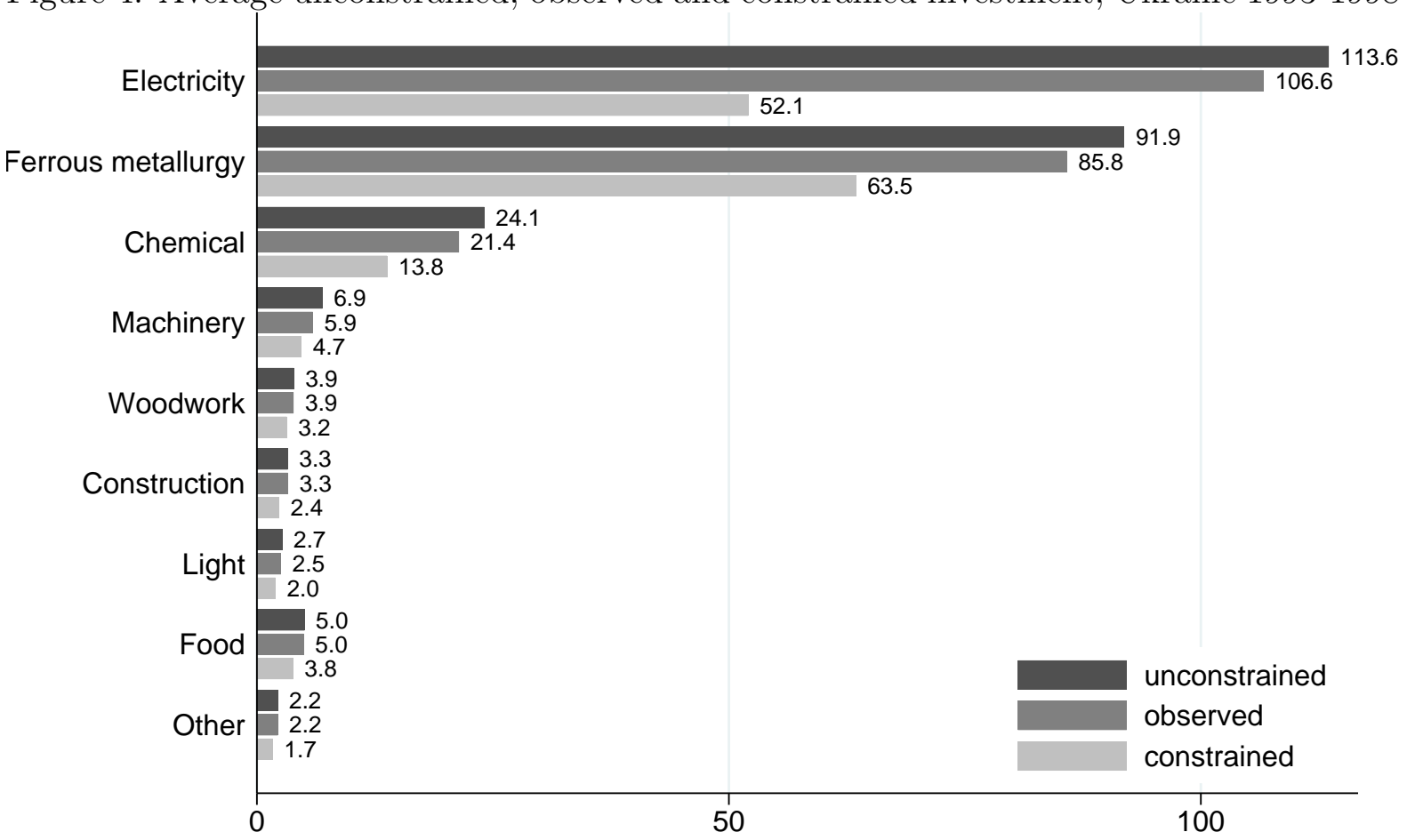

Dynamics of the probability of operating in a constrained investment regime for each industry in 1993-1998 are presented in Figure 5. For all industries but electricity generation, the probability of financial constraints declines over time. This observation is consistent with the firms learning and successfully adjusting their policy functions and resulting capital stocks to a changing economic environment. 
Figure 5: Evolution of financial constraints by industry by year, Ukraine 1993-1998
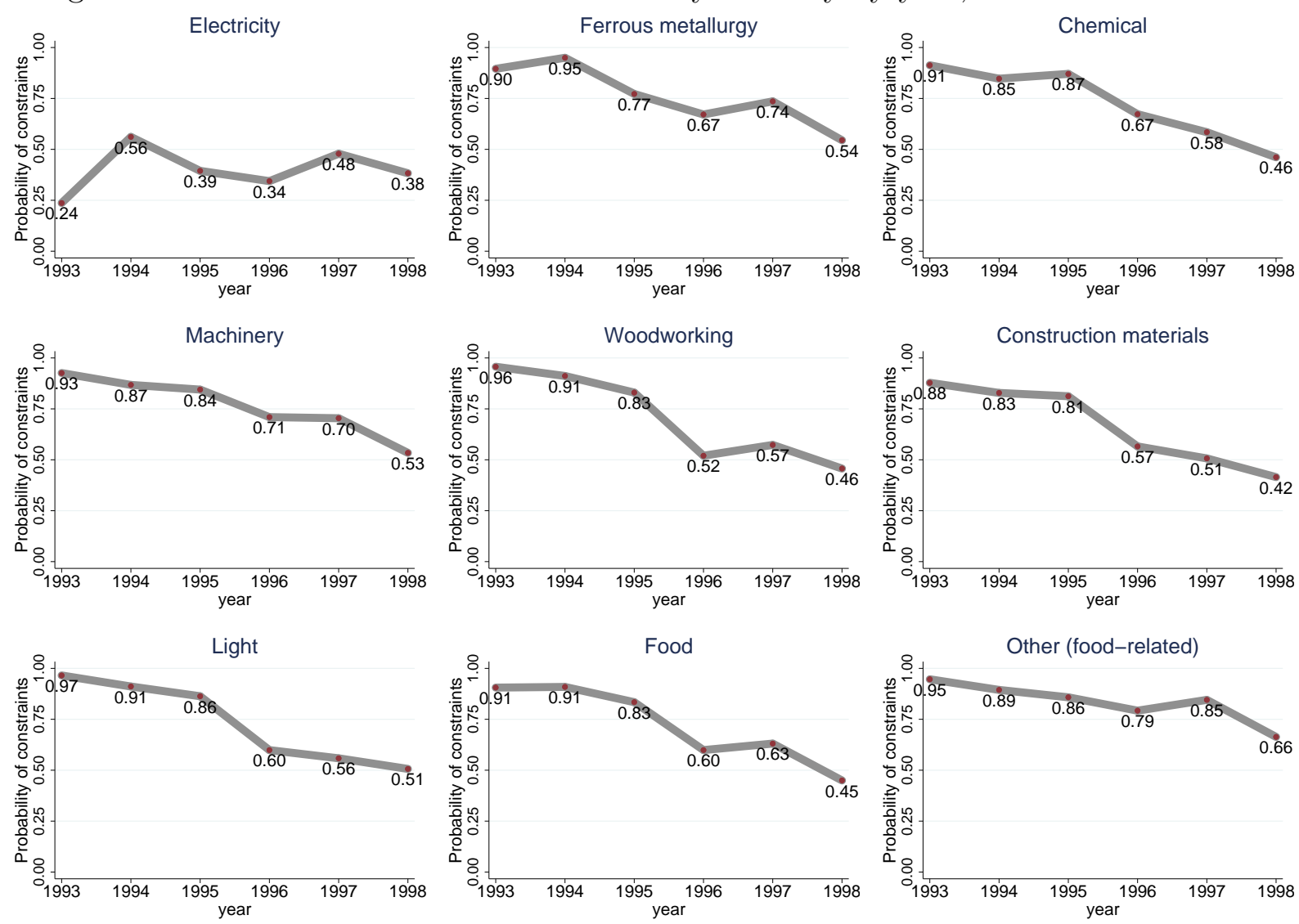

Notes: Each panel illustrates the probability of financial constraints by industry by year. All industries (but electricity) illustrate a reduction in the probability of facing borrowing constraints over time.

To quantify the difference between observed investment and optimal constrained and unconstrained predictions, I construct five measures. Table 6 summarizes the average observed investment together with constrained and unconstrained predictions for all observations in the data and, separately, for constrained observations only. 
Table 6: Summary statistics for observed, constrained and unconstrained variables

\begin{tabular}{llccccc}
\hline Sample & Variable & Mean & Median & Min & Max & S.D. \\
\hline \hline \multirow{4}{*}{ All observations } & $I^{o} / I^{u}$ & 0.918 & 0.233 & 0.000 & 42.923 & 2.285 \\
& $I^{c} / I^{u}$ & 0.682 & 0.965 & 0.000 & 1.000 & 0.414 \\
& $V^{c} / V^{u}$ & 0.990 & 0.991 & 0.969 & 1.000 & 0.007 \\
& $\left(V^{c}-V^{u}\right) / V^{u}$ & -0.010 & -0.009 & -0.031 & 0.000 & 0.007 \\
& $\left(V^{c}-V^{u}\right) / \pi^{o}$ & -0.828 & -0.053 & -334.654 & 0.000 & 6.139 \\
\hline \multirow{4}{*}{ Constrained } & $I^{o} / I^{u}$ & 0.483 & 0.173 & 0.000 & 11.252 & 0.743 \\
& $I^{c} / I^{u}$ & 0.863 & 0.978 & 0.000 & 1.000 & 0.257 \\
& $V^{c} / V^{u}$ & 0.992 & 0.992 & 0.970 & 1.000 & 0.005 \\
& $\left(V^{c}-V^{u}\right) / V^{u}$ & -0.008 & -0.008 & -0.030 & 0.000 & 0.005 \\
& $\left(V^{c}-V^{u}\right) / \pi^{o}$ & -0.488 & -0.047 & -334.654 & 0.000 & 4.031 \\
\hline \hline
\end{tabular}

Notes: Summary statistics for all observations and a sub-sample of constrained firms. Expectations represent sample averages.

The first two variables measure the ratio of observed to unconstrained investment and the ratio of constrained to unconstrained investment levels, $I^{o} / I^{u}, I^{c} / I^{u}$. The next two variables show the ratio of the constrained value function to its unconstrained counterpart, $V^{c} / V^{u}$, and evaluate losses as a percentage of the unconstrained value, $\left(V^{c}-V^{u}\right) / V^{u}$.

It turns out that, despite a high level of financial constraints, the actual losses in terms of the foregone long-run value are not very large. In particular, the maximum value attainable in a constrained regime is only 1 percent lower than the maximum value of the unconstrained firm. To provide a better sense of the magnitude of the loss, I also compute the difference between constrained and unconstrained values as a share of the per-period profit in $\left(V^{c}-V^{u}\right) / \pi^{o}$. On average the loss is about 83 percent of the realized per-period profits for all observations (the difference between constrained and unconstrained investment levels can be obtained for every observation) and 49 percent for the firms that are identified as financially constrained. ${ }^{15}$

\footnotetext{
${ }^{15}$ As discussed next, constrained firms are typically smaller but have larger profits.
} 
Table 7: Characteristics of constrained and unconstrained observations

\begin{tabular}{lcccccc}
\hline State & Capital, $K$ & Labor & Sales & Profit, $\pi$ & $\pi / K$ & Investment \\
\hline \hline Unconstrained & 462.79 & 554.27 & 666.57 & 13.40 & 0.08 & 29.56 \\
Constrained & 227.01 & 439.09 & 561.12 & 95.28 & 0.62 & 7.22 \\
\hline Total & 289.28 & 469.51 & 588.97 & 73.65 & 0.48 & 13.12 \\
\hline
\end{tabular}

Notes: Each line reports the average statistics for the variables in the header row across all unconstrained and constrained observations, respectively. Monetary variables are in thousands of USD 2011. Unconstrained firms are typically bigger in terms of capital and labor stock and have larger sales volumes. At the same time, both the level of profit and the ratio of profit to capital stock are significantly lower for the unconstrained firms. Not surprisingly, unconstrained firms invest about 4 times more than their constrained counterparts. Statistics by industry are reported in Appendix B in Table 11.

Table 7 compares observable characteristics of the firms identified as constrained and unconstrained. Summary statistics by industry can be found in Appendix B in Table 11. Constrained firms on average are smaller in terms of their capital stock and labor employed and typically have somewhat smaller sales. However, their profits and profit-to-capital ratio are substantially higher. In the data, the average observed investment of constrained firms is about four times smaller than the average investment of the unconstrained firms. These characteristics are consistent with the results from the earlier literature finding that young and potentially fast-growing firms are likely to be constrained the most. Below, I focus on a more detailed discussion of the determinants of financial constraints.

Determinants of financial constraints. In what follows, I relate the probability of financial constraints to a set of observable firm- and industry-level characteristics. In particular, I construct four alternative measures of the firm size, such as (1) the total size of capital stock in millions, Size $(K),(2)$ the number of employees in thousands, Size $(L)$, (3) the total wage bill in millions, Size $(w \times L)$, and $(4)$ the total output in millions, $\operatorname{Size}(y)$.

The profitability of fixed capital stock at the firm level is measured as the ratio of profit to the level of capital stock, $\pi / K$. While I do not have data on the ownership structure at the firm level, I use data on the average proportion of state-owned firms at the 3-digit industry level. This variable is defined as "State share." By using firm-level market shares at the 5-digit industry level, I compute $\mathrm{HHI}=\sum_{i=1}^{N} s_{i t}$, which measures the degree of market concentration in each industry. 
International trade effects are measured by export and import variables. Unfortunately, in the data I observe export/import data only for 1998. These variables are presented in levels (millions), "Export-98 lev." and "Import-98 lev.", as well as dummies with value 0 for the firms not involved in international trade and 1 for exporters and/or importers, "Export-98 dum." and "Import-98 dum.", respectively.

Finally, the last set of variables controls for the amount of non-monetary transactions at the firm level. Similar to the trade data, these variables are only available for 1998, and I use both the discrete dummy version of each of these variables as well as their levels in millions. 
Table 8: Determinants of financial constraints, Ukraine 1993-1998

\begin{tabular}{|c|c|c|c|c|c|}
\hline Variable & $(1)$ & $(2)$ & $(3)$ & $(4)$ & $(5)$ \\
\hline $\operatorname{Size}(K)$ & $\begin{array}{l}-0.001 \\
(0.004)\end{array}$ & $\begin{array}{l}-0.003 \\
(0.004)\end{array}$ & $\begin{array}{l}-0.002 \\
(0.004)\end{array}$ & & \\
\hline $\operatorname{Size}(L)$ & $\begin{array}{c}-0.013^{* * *} \\
(0.004)\end{array}$ & $\begin{array}{c}-0.010^{* * *} \\
(0.004)\end{array}$ & $\begin{array}{c}-0.013^{* * *} \\
(0.004)\end{array}$ & $\begin{array}{c}-0.014^{* * *} \\
(0.003)\end{array}$ & $\begin{array}{c}-0.016^{* * *} \\
(0.003)\end{array}$ \\
\hline $\operatorname{Size}(w \times L)$ & $\begin{array}{c}-0.011^{* *} \\
(0.005)\end{array}$ & $\begin{array}{l}-0.008^{*} \\
(0.005)\end{array}$ & $\begin{array}{c}-0.009^{*} \\
(0.005)\end{array}$ & $\begin{array}{c}-0.009 * \\
(0.005)\end{array}$ & \\
\hline $\operatorname{Size}(y)$ & $\begin{array}{c}-0.001 \\
(0.002) \\
\end{array}$ & $\begin{array}{c}-0.005^{* *} \\
(0.002)\end{array}$ & $\begin{array}{c}-0.004^{* *} \\
(0.002)\end{array}$ & $\begin{array}{c}-0.005^{* *} \\
(0.002)\end{array}$ & $\begin{array}{c}-0.006 * * * \\
(0.002)\end{array}$ \\
\hline$\pi / K$ & $\begin{array}{c}0.153^{* * *} \\
(0.003)\end{array}$ & $\begin{array}{c}0.156^{* * *} \\
(0.003)\end{array}$ & $\begin{array}{c}0.154^{* * *} \\
(0.003)\end{array}$ & $\begin{array}{c}0.154^{* * *} \\
(0.003)\end{array}$ & $\begin{array}{c}0.154^{* * *} \\
(0.003)\end{array}$ \\
\hline State share & $\begin{array}{c}0.575^{* * *} \\
(0.068)\end{array}$ & $\begin{array}{c}0.580^{* * *} \\
(0.068)\end{array}$ & $\begin{array}{c}0.575^{* * *} \\
(0.068)\end{array}$ & $\begin{array}{c}0.573^{* * *} \\
(0.068)\end{array}$ & $\begin{array}{c}0.589^{* * *} \\
(0.068)\end{array}$ \\
\hline HHI (5-digit) & $\begin{array}{c}-0.076^{* * *} \\
(0.017)\end{array}$ & $\begin{array}{c}-0.068^{* * *} \\
(0.017)\end{array}$ & $\begin{array}{c}-0.077^{* * *} \\
(0.017)\end{array}$ & $\begin{array}{c}-0.077^{* * *} \\
(0.017)\end{array}$ & $\begin{array}{c}-0.076^{* * *} \\
(0.017)\end{array}$ \\
\hline Export-98 dum. & $\begin{array}{c}0.038^{* * *} \\
(0.007)\end{array}$ & & $\begin{array}{c}0.038^{* * *} \\
(0.007)\end{array}$ & $\begin{array}{c}0.038^{* * *} \\
(0.007)\end{array}$ & $\begin{array}{c}0.038^{* * *} \\
(0.007)\end{array}$ \\
\hline Import-98 dum. & $\begin{array}{c}0.003 \\
(0.007)\end{array}$ & & $\begin{array}{c}0.001 \\
(0.007)\end{array}$ & $\begin{array}{c}0.001 \\
(0.007)\end{array}$ & $\begin{array}{c}0.001 \\
(0.007)\end{array}$ \\
\hline Export-98 lev. & & $\begin{array}{c}0.235 \\
(0.217)\end{array}$ & & & \\
\hline Import-98 lev. & & $\begin{array}{l}-0.615 \\
(0.519)\end{array}$ & & & \\
\hline GTRM-98 dum. & $\begin{array}{c}-0.007 \\
(0.006)\end{array}$ & & & & \\
\hline Barter-98 dum. & $\begin{array}{c}0.006 \\
(0.005)\end{array}$ & & & & \\
\hline GTRM-98 lev. & & $\begin{array}{c}0.746^{* * *} \\
(0.192)\end{array}$ & $\begin{array}{c}0.625^{* * *} \\
(0.185)\end{array}$ & $\begin{array}{c}0.624^{* * *} \\
(0.185)\end{array}$ & $\begin{array}{c}0.655^{* * *} \\
(0.184)\end{array}$ \\
\hline Barter-98 lev. & & $\begin{array}{c}0.379^{* *} \\
(0.147) \\
\end{array}$ & $\begin{array}{c}0.355^{* *} \\
(0.141) \\
\end{array}$ & $\begin{array}{c}0.347^{* *} \\
(0.140)\end{array}$ & $\begin{array}{c}0.340^{* *} \\
(0.139)\end{array}$ \\
\hline Constant & $\begin{array}{c}0.054 \\
(0.062) \\
\end{array}$ & $\begin{array}{c}0.054 \\
(0.062)\end{array}$ & $\begin{array}{c}0.060 \\
(0.062)\end{array}$ & $\begin{array}{c}0.059 \\
(0.062)\end{array}$ & $\begin{array}{c}0.047 \\
(0.061)\end{array}$ \\
\hline $\begin{array}{l}\text { Year dum. } \\
\text { 3-digit ind. dum. }\end{array}$ & $\begin{array}{l}\text { yes } \\
\text { yes }\end{array}$ & $\begin{array}{l}\text { yes } \\
\text { yes }\end{array}$ & $\begin{array}{l}\text { yes } \\
\text { yes }\end{array}$ & $\begin{array}{l}\text { yes } \\
\text { yes }\end{array}$ & $\begin{array}{l}\text { yes } \\
\text { yes }\end{array}$ \\
\hline $\begin{array}{l}\text { Observations } \\
R \text {-squared }\end{array}$ & $\begin{array}{c}33,232 \\
0.223\end{array}$ & $\begin{array}{c}33,232 \\
0.223\end{array}$ & $\begin{array}{c}33,232 \\
0.224\end{array}$ & $\begin{array}{c}33,232 \\
0.224\end{array}$ & $\begin{array}{c}33,253 \\
0.224\end{array}$ \\
\hline
\end{tabular}

Notes: Linear probability models. The dependent variable is the probability of financial constraints, $\operatorname{Pr}($ con $)$. Standard errors are in parentheses: ${ }^{* * *} \mathrm{p}<0.01,{ }^{* *} \mathrm{p}<0.05,{ }^{*} \mathrm{p}<0.10$. 
Table 8 summarizes the linear probability model regression of a regime $(0=$ unconstrained, $1=$ constrained) on a set of observed industry- and firm-level characteristics. Each specification includes year and 3-digit industry dummy variables.

Estimation results suggest that larger firms in terms of capital stock, labor, total wage bill and total output are less likely to face borrowing restrictions. The number of employees and the output level have the strongest negative effect on the probability of financial constraints. Also, firms that were identified as financially constrained on average have higher returns on capital. These findings are in line with the findings from the earlier literature (see e.g., Calomiris and Hubbard, 1995; Beck et al., 2005).

Interestingly, state involvement measured as the share of state ownership at the 3-digit industry level is associated with the higher level of financial constraints. It is possible that the state governance and non-transparent accounting indeed reduced returns on capital stock and decreased the interest of private investors. Lower demand and supply from private investors apparently was not compensated by the government finance and the overall effect of state ownership turned out to be negative. Discussion of the potential endogeneity problem (when there is a selection on the characteristics of the firms subject to privatization) and a possible way to address it using the instrumental variable approach is provided below.

The industry concentration measure has a negative effect on the probability of financial constraints. This can be explained by the higher return on capital stock in more concentrated markets. It is worth noting that the theory model in this paper assumes single-agent maximization, while in very concentrated industries firms are likely to be strategic and take the strategies of other players into account. Hence, the finding that HHI reduces the probability of financial constraints due to the higher returns should be considered with caution. It turns out that when potential endogeneity of the concentration measure is taken into account, the effect of market concentration on the probability of financial constraints becomes insignificant (for example, see Table 12 in Appendix B.2).

An obvious caveat to the results presented in Table 8 is that the return on capital, $\pi / K$, State share, and HHI (5-digit) variables may be subject to a reverse causality problem. I address this potential endogeneity problem in Appendix B.2 in Table 12. When potentially endogenous right-hand-side variables are instrumented with their own lagged values, the results generally agree with the ones reported in Table 8 above. IV specifications estimate 
statistically significant positive coefficients on $\pi / K$ and State share. ${ }^{16}$ However, the coefficient on HHI in the IV regressions becomes statistically not different from zero, which may be a consequence of the aforementioned endogeneity problem.

The effect of firms' involvement in international trade is addressed using measures of export and import operations available for the last year in the sample, which is 1998 . Under the assumption that firms that were exporting/importing in 1998 were doing so for the entire sample period, I can conclude that exporting firms tend to face financial constraints with higher probability than the ones producing for the domestic markets. It is possible that depreciation of the domestic currency and access to bigger markets generated so high a demand for investment that firms had to borrow, which was not always possible in an environment of asymmetric information. Importing does not seem to have an important effect on the likelihood of financial constraints. One possible explanation is that importing firms were often engaged in non-monetary transaction schemes such as give-and-take-raw-materials and barter with their foreign partners, which is discussed next.

Firms that had large levels of barter or toll schemes in their output in 1998 tend to be significantly more likely financially constrained. This finding is not surprising given that such transactions typically increase production costs and make accounting less transparent. The former can reduce the level of their own resources available for reinvestment, while the latter may significantly increase the risk premium set by the external lenders, making borrowing prohibitively costly. For example, if the non-monetary transactions are transitory and not expected to persist in the long run, the value of the firms should be affected much less than the current period cash flows, which could otherwise be used to finance capital investment.

\section{Conclusions}

In this study I develop and estimate a model of firm-level fixed capital investment when access to external financial resources may be limited and retained earnings may be insufficient to secure an optimal investment choice. The main contribution of the paper is in the application of the nested fixed-point algorithm solving for dynamically optimal

\footnotetext{
${ }^{16}$ Point estimates for these variables are actually larger in the instrumental variable regressions.
} 
investment with and without the ability to borrow. Differently from the models based on the first-order conditions for dynamic control (empirical Euler equations), constrained firms endogenize the likelihood of facing borrowing restrictions in the future and adjust their dynamic policy accordingly. In particular, they take into account that a unit of investment today not only increases future capital stock but also reduces the likelihood of having to borrow in the future. I estimate structural parameters of the model using data from the Ukrainian manufacturing register in 1993-1998.

In 1993-1998, the overall level of financial constraints in Ukrainian manufacturing was high. The lowest level of financial constraints was detected in electricity generation with only 40 percent of observations identified as financially constrained. The highest level of financial constraints was detected in the other (food-related) industry, where only 15 percent of firms could borrow. In the rest of the industries, the share of firms identified as unconstrained ranges between 23 and 30 percent. Despite the high probability of financial constraints, the actual firm-level investments were closer to the unconstrained predictions.

Over time the probability of a constrained investment regime declined substantially in all industries but electricity generation. The reduction in the probability of financial constraints can be explained by firms successfully adjusting their investment policies and capital stock to a new economic environment. For example, profitable and growing but constrained firms over time can improve their accounting standards, establish their reputation and provide other signals that increase their collateral value and access to external funds.

According to the estimation results, constrained firms are typically smaller firms having higher returns on capital. This finding is consistent with the earlier literature where small and fast-growing firms tend to be more financially constrained. At the same time, the overall long-run losses from sub-optimal investment are not very large and on average constitute about 1 percent of the long-run value of an unconstrained firm. When compared to the realized profits, investment constraints reduce firm value by an equivalent of about 49 percent of the per-period profit for the constrained observations.

State ownership is associated with a much higher likelihood of facing financial constraints, while industry concentration may help in reducing them. Exporting firms were identified as experiencing borrowing restrictions with a higher probability than domestically-oriented producers. There is no evidence that import operations matter for 
the firm-level fixed capital investment. Finally, high volumes of non-monetary transactions such as barter and toll schemes can significantly increase the probability of financial constraints for the firms that are engaged in such transactions.

\section{References}

Beck, T., Demirguc-Kunt, A. and Maksimovic, V. (2005). Financial and legal constraints to growth: Does firm size matter? The Journal of Finance, 60(1):137-177.

Bernstein, J. and Nadiri, I. (1988). Financing and investment in plant and equipment and research and development. In Preston, M. H. and Quandt, R. E., editors, Prices, Competition and Equilibrium, pages 233-248. New York: Phillip Allan.

Bond, S. and Meghir, C. (1994). Dynamic investment models and the firm's financial policy. The Review of Economic Studies, 61(2):197-222.

Calomiris, C. and Hubbard, G. (1990). Firm heterogeneity, internal finance, and 'credit rationing'. The Economic Journal, 100:90-104.

Calomiris, C. and Hubbard, G. (1995). Internal finance and investment: Evidence from the undistributed profits tax of 1936-37. The Journal of Business, 68(4):443-482.

Chatelain, J.-B. (2002). Structural modelling of financial constraints on investment: Where do we stand? Working Paper 28, National Bank of Belgium.

Chirinko, R. (1993). Business fixed investment spending: modeling strategies, empirical results, and policy implications. Journal of Economic Literature, 31:1875-1911.

Ericson, R. and Pakes, A. (1995). Markov-perfect industry dynamics: a framework for empirical work. The Review of Economic Studies, 62(1):53-82.

Fazzari, S. and Athey, M. (1987). Asymmetric information, financing constraints, and investment. The Review of Economics and Statistics, 69(3):481-487.

Fazzari, S., Hubbard, G. and Petersen, B. (1988). Financing constraints and corporate investment. Brookings Papers on Economic Activity, 1988(1):141-206. 
Fazzari, S., Hubbard, G. and Petersen, B. (2000). Investment-cash flow sensitivities are useful: A comment on Kaplan and Zingales. The Quarterly Journal of Economics, 115(2):695-705.

Fazzari, S. and Mott, T. (1986). The investment theories of Kalecki and Keynes: an empirical study of firm data, 1970-1982. Journal of Post Keynesian Economics, 9:171187.

Greenwald, B., Stiglitz, J. and Weiss, A. (1984). Informational imperfections in the capital market and macroeconomic fluctuations. The American Economic Review, 74(2):194-199.

Hansen, L. and Singleton, K. (1982). Generalized instrumental variables estimation of nonlinear rational expectations models. Econometrica, 50(5):1269-1286.

Hovakimian, G. and Titman, S. (2006). Corporate investment with financial constraints: Sensitivity of investment to funds from voluntary asset sales. Journal of Money, Credit and Banking, 38(2):357-374.

Hubbard, G. (1998). Capital-market imperfections and investment. Journal of Economic Literature, 36:193-225.

Kaplan, S. and Zingales, L. (1997). Do investment-cash flow sensitivities provide useful measures of financing constraints? The Quarterly Journal of Economics, 112(1):169-215.

Kaplan, S. and Zingales, L. (2000). Investment-cash flow sensitivities are not valid measures of financial constraints. The Quarterly Journal of Economics, 115(2):707-712.

Kopcke, R. (1985). The determinants of investment spending. New England Economic Review, pages 19-35.

Lamont, O. (1997). Cash flow and investment: Evidence from internal capital markets. The Journal of Finance, 52(1):83-109.

Myers, S. and Majluf, N. (1984). Corporate financing decisions when firms have investment information that investors do not. Journal of Financial Economics, 13:187-220.

Oliner, S. and Rudebusch, G. (1992). Sources of the financing hierarchy for business investment. The Review of Economics and Statistics, 74(4):643-654. 
Sinai, A. and Eckstein, O. (1983). Tax policy and business fixed investment revisited. Journal of Economic Behavior and Organization, 4:131-162. 


\section{Appendix A Additional reduced-form evidence of financial constraints}

\section{Appendix A.1 Split-sample regressions based on observed returns}

To further explore the relationship between observed variables approximating cash flows and investment behavior, I split the data into sub-samples with relatively high profit-to-capital stock ratios and sub-samples with relatively low profit-to-capital stock ratios. Then I estimate an empirical Euler equation (12) for each of the sub-samples.

High profitability of the capital stock can be associated with higher investment activity for two reasons. One of the reasons is the binding constraint on the available resources (2b), which is a function of firms' own retained earnings. In this case, firms with low (current) levels of their own financial resources would have to rely on the external funds, while firms with high profitability of capital can invest more by redirecting their profits to investment into fixed capital. In other words, firms with higher current profits should also have larger investments, while this link is expected to be weaker for the firms using a combination of their own and external finances.

Table 9: Additional reduced-form evidence of financial constraints in 1993-1998 in Ukraine

\begin{tabular}{lcc|cc}
\multirow{2}{*}{ Variables } & \multicolumn{2}{c|}{ Quintiles } & \multicolumn{2}{c}{ Tertiles } \\
\cline { 2 - 5 } & bottom 20\% & top 20\% & bottom 33\% & top 33\% \\
\hline$\alpha_{0}=$ constant & 0.029 & -0.058 & 0.012 & -0.064 \\
$\alpha_{1}=I_{i t} / K_{i t}$ & $(0.079)$ & $(0.089)$ & $(0.062)$ & $(0.071)$ \\
& $0.138^{* *}$ & $0.171^{* * *}$ & $0.275^{* * *}$ & $0.260^{* * *}$ \\
$\alpha_{2}=\pi_{i t} / K_{i t}$ & $(0.063)$ & $(0.052)$ & $(0.055)$ & $(0.048)$ \\
& $-0.016^{* *}$ & $0.033^{* * *}$ & $-0.017^{*}$ & $0.034^{* * *}$ \\
$\alpha_{3}=$ sales $_{i t} / K_{i t}$ & $(0.008)$ & $(0.004)$ & $(0.009)$ & $(0.004)$ \\
& 0.001 & $-0.001^{* * *}$ & 0.001 & $-0.001^{* * *}$ \\
$\alpha_{4}=$ output $_{i t} / K_{i t}$ & $(0.002)$ & $(0.000)$ & $(0.002)$ & $(0.000)$ \\
& 0.008 & $0.010^{* * *}$ & 0.008 & $0.011^{* * *}$ \\
\hline Year dummies & $(0.006)$ & $(0.001)$ & $(0.006)$ & $(0.001)$ \\
Industry dummies & yes & yes & yes & yes \\
\hline Observations & yes & yes & yes & yes \\
R-squared & 4,849 & 4,844 & 8,075 & 8,080 \\
\hline F-test $\left(\alpha_{2}=\alpha_{3}=\alpha_{4}=0\right)$ & 0.013 & 0.088 & 0.009 & 0.076 \\
p-val & 3.650 & 74.98 & 3.094 & 76.09 \\
\hline \hline Notes: Stamb & 0.0121 & 0 & 0.0258 & 0 \\
\hline
\end{tabular}

Notes: Standard errors are in parentheses: ${ }^{* * *} \mathrm{p}<0.01,{ }^{* *} \mathrm{p}<0.05,{ }^{*} \mathrm{p}<0.1$. The sample includes only firms with positive investment levels. The sample is split according to the level of $\pi_{i t} / K_{i t}$. Columns 2 and 3 (quintiles) illustrate estimation results for the observations in the top and bottom $20 \%$ of the distribution. Columns 4 and 5 (tertiles) report estimates for the observations in the top and bottom $33 \%$ of the distribution.

As is apparent from Table 9, investments by the firms in the bottom quintile (tertile) of profitability illustrate smaller coefficients on the cash flow proxy variables (both in terms of 
their value and statistical significance) than the coefficients in the investment equations of the firms located at the highest quintile (tertile).

It is worth noting that if the proxy variables indeed contain extra information about the future prospects of the firm and this information is different from what is captured by the industry- and time-varying coefficients in the empirical Euler equation, then both constrained and unconstrained firms should have positive statistically significant coefficients on the cash flow variables.

To further justify the significance of cash flow variables for the firm-level investment decisions, I instrument these variables with their one-period-lagged values. The idea is that the endogeneity problem, when the same shock affects both the current period return on capital and firm investment opportunities, is alleviated if we instrument current period values of the cash flow proxy variables with their lagged values. This is because, at the point in time firms form expectations about the current period, the shocks have not yet been realized.

\section{Appendix A.2 Instrumental variable regressions for reduced-form evidence}

Table 10 summarizes the regressions presented in Table 4, where cash flow variables are instrumented by their one-period-lagged values.

Table 10: Instrumental variable version of OLS regressions in Table 4

\begin{tabular}{lcccc}
\hline Variables & $(1)$ & $(2)$ & $(3)$ & $(4)$ \\
\hline \hline Constant & 0.036 & -0.006 & -0.045 & -0.026 \\
& $(0.041)$ & $(0.041)$ & $(0.043)$ & $(0.076)$ \\
$I_{i t} / K_{i t}$ & $0.504^{* * *}$ & -0.061 & $0.352^{* * *}$ & $0.345^{* * *}$ \\
& $(0.048)$ & $(0.067)$ & $(0.034)$ & $(0.036)$ \\
\hline$\pi_{i t} / K_{i t}$ & $0.086^{* * *}$ & & & 0.013 \\
& $(0.022)$ & & & $(0.092)$ \\
sales $_{i t} / K_{i t}$ & & $0.019^{* * *}$ & & 0.003 \\
& & $(0.003)$ & & $(0.016)$ \\
output & it $/ K_{i t}$ & & $0.022^{* * *}$ & $0.015^{*}$ \\
& & & $(0.005)$ & $(0.009)$ \\
\hline Year dummies & & yes & yes & yes \\
Industry dummies & yes & yes & yes & yes \\
\hline Observations & 23,338 & 23,532 & 23,549 & 23,282 \\
Test CF-variable(s) $=0$ & 15.56 & 57.25 & 21.85 & 22.04 \\
p-val & $8.01 \mathrm{e}-05$ & 0 & $2.94 \mathrm{e}-06$ & $6.41 \mathrm{e}-05$ \\
\hline \hline
\end{tabular}

Notes: IV specifications with the dependent variable $y_{i t}=\frac{1}{2}\left(\frac{I_{i t+1}}{K_{i t+1}}\right)^{2}+\delta\left(\frac{I_{i t+1}}{K_{i t+1}}\right)$. Standard errors are in parentheses: ${ }^{* * *} \mathrm{p}<0.01,{ }^{* *} \mathrm{p}<0.05,{ }^{*} \mathrm{p}<0.1$. Specifications in columns (1) through (4) are the instrumental variable versions of the OLS regressions reported in Table 4. Columns (1), (2), (3) and (4) in the table above correspond to columns (2), (3), (4) and (5) in Table 4, respectively.

Coefficient estimates on the cash flow variables instrumented with own lagged values turn 
out to be positive and statistically significant. The test for (joint) significance of the proxy variables is reported in the bottom two lines in Table 10. 


\section{Appendix B Additional summary statistics for estimation results}

\section{Appendix B.1 Characteristics of constrained and unconstrained firms by industry}

Table 11 summarizes average values of the key variables for unconstrained and constrained observations, respectively.

Table 11: Summary statistics for key variables by regime, Ukraine 1993-1998

\begin{tabular}{|c|c|c|c|c|c|c|}
\hline State & Capital, $K$ & Labor & Sales & Profit, $\pi$ & $\pi / K$ & Investment \\
\hline \multicolumn{7}{|c|}{ Electricity } \\
\hline unconstrained & 1733.82 & $1475 . \overline{35}$ & 1927.35 & 30.16 & 0.02 & 120.26 \\
\hline constrained & 1866.19 & 1268.37 & 4116.71 & 660.67 & 0.41 & 85.92 \\
\hline \multicolumn{7}{|c|}{ Ferrous metallurgy } \\
\hline unconstrained & 3147.68 & 2625.21 & 7152.95 & 110.10 & 0.13 & 156.78 \\
\hline constrained & 2008.15 & 1957.70 & 4578.16 & 891.50 & 0.52 & 62.68 \\
\hline \multicolumn{7}{|c|}{$\underline{\text { Chemical }}$} \\
\hline unconstrained & 1124.78 & 1108.19 & 1305.40 & 30.27 & 0.07 & 47.45 \\
\hline constrained & 620.05 & 830.73 & 1201.28 & 201.89 & 0.54 & 11.65 \\
\hline \multicolumn{7}{|c|}{ Machinery } \\
\hline unconstrained & 270.62 & $595.0 \overline{6}$ & 230.02 & 5.58 & 0.04 & 13.82 \\
\hline constrained & 216.58 & 693.33 & 341.55 & 65.64 & 0.36 & 3.53 \\
\hline \multicolumn{7}{|c|}{ Woodworking } \\
\hline unconstrained & 101.84 & 303.61 & 217.96 & 4.82 & 0.06 & 7.85 \\
\hline constrained & 67.26 & 303.59 & 241.16 & 38.86 & 0.71 & 2.49 \\
\hline \multicolumn{7}{|c|}{ Construction materials } \\
\hline unconstrained & 115.49 & 216.24 & 151.32 & 1.41 & 0.01 & 5.49 \\
\hline constrained & 99.60 & 262.82 & 188.23 & 26.55 & 0.26 & 2.33 \\
\hline \multicolumn{7}{|c|}{ Light } \\
\hline unconstrained & 84.30 & 356.33 & 166.91 & 4.50 & 0.06 & 4.93 \\
\hline constrained & 61.72 & 449.22 & 228.34 & 49.23 & 0.96 & 1.83 \\
\hline \multicolumn{7}{|c|}{ Food } \\
\hline unconstrained & 92.22 & 174.09 & 346.74 & 11.93 & 0.16 & 9.62 \\
\hline constrained & 67.52 & 189.37 & 419.96 & 60.52 & 0.88 & 3.36 \\
\hline \multicolumn{7}{|c|}{ Other food-related } \\
\hline unconstrained & 75.29 & 140.86 & 226.14 & 11.31 & 0.19 & 8.53 \\
\hline constrained & 41.62 & 98.47 & 190.41 & 28.54 & 0.73 & 1.06 \\
\hline
\end{tabular}

Notes: Each line reports the average statistics for the variables in the header row across all unconstrained and constrained observations, respectively. Monetary variables are in thousands USD 2011. Unconstrained firms are typically bigger in terms of capital and labor stock and have larger sales volumes. However, both the level of profit and the ratio of profit to capital stock are significantly lower for the unconstrained firms. 


\section{Appendix B.2 IV versions of Table 8 for HHI and state ownership}

Table 12: Determinants of financial constraints, IV regressions, Ukraine 1993-1998

\begin{tabular}{|c|c|c|c|c|}
\hline Variable & (1) & $(2)$ & (3) & (4) \\
\hline$\overline{\operatorname{Size}(L)}$ & $\begin{array}{c}-0.023^{* * *} \\
(0.004)\end{array}$ & $\begin{array}{c}-0.025^{* * *} \\
(0.004)\end{array}$ & $\begin{array}{c}-0.024^{* * *} \\
(0.004)\end{array}$ & $\begin{array}{c}-0.021^{* * *} \\
(0.004)\end{array}$ \\
\hline $\operatorname{Size}(y)$ & $\begin{array}{c}-0.008^{* * *} \\
(0.002)\end{array}$ & $\begin{array}{c}-0.006^{* *} \\
(0.002)\end{array}$ & $\begin{array}{c}-0.007^{* * *} \\
(0.002)\end{array}$ & $\begin{array}{c}-0.007^{* * *} \\
(0.002)\end{array}$ \\
\hline$\pi / K$ & & $\begin{array}{c}0.221^{* * *} \\
(0.005)\end{array}$ & $\begin{array}{c}0.222^{* * *} \\
(0.005)\end{array}$ & \\
\hline State share & $\begin{array}{c}0.248^{* * *} \\
(0.091)\end{array}$ & & $\begin{array}{c}0.290^{* * *} \\
(0.091)\end{array}$ & \\
\hline$H H I$ (5-digit) & $\begin{array}{c}0.021 \\
(0.023) \\
\end{array}$ & $\begin{array}{c}0.015 \\
(0.023) \\
\end{array}$ & & \\
\hline$\widehat{\pi / K}$ & $\begin{array}{c}0.264^{* * *} \\
(0.010)\end{array}$ & & & $\begin{array}{c}0.263^{* * *} \\
(0.010)\end{array}$ \\
\hline State share & & $\begin{array}{c}0.766^{* * *} \\
(0.248)\end{array}$ & & $\begin{array}{c}0.729^{* * *} \\
(0.245)\end{array}$ \\
\hline$H H \widehat{I(5-d i g i t)}$ & & & $\begin{array}{c}-0.008 \\
(0.031) \\
\end{array}$ & $\begin{array}{c}0.006 \\
(0.032) \\
\end{array}$ \\
\hline Export-98 dum. & $\begin{array}{c}0.036^{* * *} \\
(0.008)\end{array}$ & $\begin{array}{c}0.038^{* * *} \\
(0.008)\end{array}$ & $\begin{array}{c}0.039^{* * *} \\
(0.008)\end{array}$ & $\begin{array}{r}0.036^{* * *} \\
(0.008)\end{array}$ \\
\hline Import-98 dum. & $\begin{array}{c}-0.008 \\
(0.009)\end{array}$ & $\begin{array}{c}-0.001 \\
(0.009)\end{array}$ & $\begin{array}{c}-0.001 \\
(0.009)\end{array}$ & $\begin{array}{l}-0.008 \\
(0.009)\end{array}$ \\
\hline GTRM-98 lev. & $\begin{array}{c}0.863^{* * *} \\
(0.223)\end{array}$ & $\begin{array}{c}0.879^{* * *} \\
(0.223)\end{array}$ & $\begin{array}{c}0.884^{* * *} \\
(0.223)\end{array}$ & $\begin{array}{c}0.861^{* * *} \\
(0.223)\end{array}$ \\
\hline Barter-98 lev. & $\begin{array}{c}0.317^{*} \\
(0.172)\end{array}$ & $\begin{array}{c}0.285^{*} \\
(0.173)\end{array}$ & $\begin{array}{c}0.298^{*} \\
(0.172)\end{array}$ & $\begin{array}{c}0.270 \\
(0.173) \\
\end{array}$ \\
\hline Constant & $\begin{array}{c}0.348^{* * *} \\
(0.079)\end{array}$ & $\begin{array}{l}-0.072 \\
(0.209)\end{array}$ & $\begin{array}{c}0.330^{* * *} \\
(0.079)\end{array}$ & $\begin{array}{l}-0.052 \\
(0.208)\end{array}$ \\
\hline Year dum. & yes & yes & yes & yes \\
\hline 3-digit ind. dum. & yes & yes & yes & yes \\
\hline Observations & 23,097 & 23,029 & 23,032 & 22,987 \\
\hline$R$-squared & 0.211 & 0.212 & 0.213 & 0.209 \\
\hline
\end{tabular}

Notes: IV regressions for the linear probability models in Table 8 . Standard errors are in parentheses: ${ }^{* *} \mathrm{p}<0.01,{ }^{* *} \mathrm{p}<0.05,{ }^{*} \mathrm{p}<0.10$. The dependent variable is the probability of financial constraints, $\operatorname{Pr}($ con $)$. Variables denoted with hats are instrumented with their own one-period-lagged values. Estimation of both stages is done jointly. Specifications (1) through (3) instrument only one of the controls, while specification (4) uses instruments for all three control variables on the RHS. Variables measuring firms' involvement in international trade and non-monetary transaction are available only for 1998 and are not instrumented. 


\section{Appendix C First stage and continuously updated GMM results}

Table 13: Estimates of structural parameters, first stage GMM, Ukraine, 1993-1998

\begin{tabular}{lccccccccc}
\hline & Electr. & $\begin{array}{c}\text { Ferr. } \\
\text { met. }\end{array}$ & Chemic. & Machin. & $\begin{array}{c}\text { Wood- } \\
\text { working }\end{array}$ & $\begin{array}{c}\text { Constr. } \\
\text { mat. }\end{array}$ & Light & Food & Other \\
\hline \hline Adj.cost., $b$ & 7.584 & 35.856 & 26.235 & 23.690 & 5.525 & 8.973 & 13.741 & 14.246 & 29.759 \\
(s.e.) & $(0.092)$ & $(0.191)$ & $(0.066)$ & $(0.697)$ & $(0.613)$ & $(0.090)$ & $(1.218)$ & $(1.350)$ & $(0.346)$ \\
Inv.price, $p_{I}$ & 0.843 & 0.931 & 0.911 & 0.552 & 1.440 & 0.408 & 1.355 & 1.891 & 1.829 \\
(s.e.) & $(0.025)$ & $(0.063)$ & $(0.036)$ & $(0.048)$ & $(0.053)$ & $(0.040)$ & $(0.083)$ & $(0.116)$ & $(0.141)$ \\
1-depr., $\delta$ & 0.899 & 0.922 & 0.911 & 0.902 & 0.898 & 0.886 & 0.901 & 0.897 & 0.896 \\
(s.e.) & $(0.002)$ & $(0.002)$ & $(0.002)$ & $(0.001)$ & $(0.002)$ & $(0.001)$ & $(0.001)$ & $(0.001)$ & $(0.001)$ \\
\hline Pr(unc) & 0.60 & 0.25 & 0.27 & 0.23 & 0.26 & 0.30 & 0.23 & 0.25 & 0.15 \\
\hline E[I(con)] & 51.68 & 61.15 & 13.65 & 4.34 & 3.48 & 2.69 & 2.17 & 4.23 & 2.02 \\
E[I(obs)] & 106.64 & 85.80 & 21.41 & 5.91 & 3.89 & 3.28 & 2.55 & 4.97 & 2.21 \\
E[I(unc)] & 110.84 & 88.20 & 23.79 & 6.32 & 4.45 & 3.79 & 3.01 & 5.71 & 2.71 \\
\hline Num. obs. & 2,417 & 883 & 1,060 & 9,433 & 2,451 & 4,506 & 3,036 & 10,307 & 4,378 \\
Stg.2 f-val. & $10,377.760$ & $4,364.608$ & 123.287 & $1,090.727$ & 409.066 & 674.710 & 130.631 & $1,610.531$ & 249.857 \\
p(J-stat) & 0.00 & 0.00 & 0.00 & 0.00 & 0.00 & 0.00 & 0.00 & 0.00 & 0.00 \\
\hline \hline Notes: All specifications report the first step of the tho-step optiml GMM. Standard ents
\end{tabular}

Notes: All specifications report the first step of the two-step optimal GMM. Standard errors are in parentheses. Parameter $\delta$ is equal to 1-depreciation rate of capital. $\operatorname{Pr}($ unc $)$ reports the average probability that firms have access to external funds, i.e., can borrow. $\mathbb{E}\left[I_{i t}^{c}\right], \mathbb{E}\left[I_{i t}^{o}\right]$ and $\mathbb{E}\left[I_{i t}^{u}\right]$ report industry average constrained, observed and unconstrained investment levels, respectively. $\mathrm{p}(\mathrm{J}$-stat $)$ reports the p-value of Hansen's J-statistic.

Table 14: Estimates of structural parameters, continuously updated GMM, Ukraine, 1993-1998

\begin{tabular}{lccccccccc}
\hline & Electr. & $\begin{array}{c}\text { Ferr. } \\
\text { met. }\end{array}$ & Chemic. & Machin. & $\begin{array}{c}\text { Wood- } \\
\text { working }\end{array}$ & $\begin{array}{c}\text { Constr. } \\
\text { mat. }\end{array}$ & Light & Food & Other \\
\hline \hline Adj.cost., $b$ & 7.533 & 35.897 & 26.229 & 23.702 & 8.081 & 8.487 & 18.576 & 14.486 & 29.747 \\
(s.e.) & $(0.511)$ & $(2.457)$ & $(1.835)$ & $(0.325)$ & $(0.430)$ & $(0.615)$ & $(1.020)$ & $(0.428)$ & $(13.283)$ \\
Inv.price, $p_{I}$ & 0.880 & 0.963 & 0.943 & 0.533 & 1.425 & 0.479 & 1.278 & 2.058 & 2.146 \\
(s.e.) & $(0.028)$ & $(0.065)$ & $(0.079)$ & $(0.016)$ & $(0.025)$ & $(0.012)$ & $(0.022)$ & $(0.002)$ & $(0.423)$ \\
1-depr., $\delta$ & 0.906 & 0.928 & 0.915 & 0.908 & 0.908 & 0.892 & 0.907 & 0.904 & 0.900 \\
(s.e.) & $(0.002)$ & $(0.002)$ & $(0.002)$ & $(0.001)$ & $(0.002)$ & $(0.001)$ & $(0.001)$ & $(0.001)$ & $(0.001)$ \\
\hline Pr(unc) & 0.60 & 0.25 & 0.27 & 0.23 & 0.26 & 0.30 & 0.23 & 0.26 & 0.15 \\
\hline E[I(con)] & 52.481 & 63.46 & 13.78 & 4.718 & 2.967 & 2.385 & 1.909 & 3.841 & 1.662 \\
E[I(obs)] & 106.636 & 85.80 & 21.41 & 5.912 & 3.888 & 3.280 & 2.547 & 4.967 & 2.205 \\
E[I(unc)] & 113.586 & 91.87 & 24.08 & 6.936 & 4.024 & 3.267 & 2.726 & 5.013 & 2.186 \\
\hline Num. obs. & 2,417 & 883 & 1,060 & 9,433 & 2,451 & 4,506 & 3,036 & 10,307 & 4,378 \\
Stg.2 f-val. & 0.256 & 0.407 & 0.053 & 2.603 & 0.804 & 1.702 & 0.591 & 7.032 & 3.131 \\
p(J-stat) & 0.61 & 0.52 & 0.82 & 0.11 & 0.37 & 0.19 & 0.44 & 0.01 & 0.08 \\
\hline \hline
\end{tabular}

Notes: All specifications report continuously updated GMM estimation results. Standard errors are in parentheses. Parameter $\delta$ is equal to 1-depreciation rate of capital. $\operatorname{Pr}($ unc) reports the average probability that firms have access to external funds, i.e., can borrow. $\mathbb{E}\left[I_{i t}^{c}\right], \mathbb{E}\left[I_{i t}^{o}\right]$ and $\mathbb{E}\left[I_{i t}^{u}\right]$ report industry average constrained, observed and unconstrained investment levels, respectively. $\mathrm{p}(\mathrm{J}$-stat) reports the p-value of Hansen's J-statistic. 